\title{
“They Enjoy Syrup and Ghee at Tables of Silver and Gold": Infant Loss in Ancient Mesopotamia
}

\author{
Jonathan Valk \\ Institute for the Study of the Ancient World, New York University \\ jonathan.valk@nyu.edu
}

\begin{abstract}
The present study draws on interdisciplinary research to establish an interpretative framework for an analysis of the material and textual evidence concerning infant loss in ancient Mesopotamia (c. 3000-500 BCE). This approach rejects the notion that high infant mortality rates result in widespread parental indifference to infant loss, arguing instead that underlying biological and transcultural realities inform human responses to this phenomenon. With this conclusion in mind, a review of ancient Mesopotamian archaeological evidence reveals patterns of differential infant burial; while the interpretation of these patterns is uncertain, the broader contexts of infant burials in ancient Mesopotamia do not point to parental indifference, but rather the opposite. The available textual evidence in turn indicates that ancient Mesopotamians valued their infants, sought actively to protect them from harm, and mourned deeply when they died, a conclusion that is not controverted by evidence of infant exposure.
\end{abstract}

\section{Keywords}

Mesopotamia - infant - social history - parental indifference - mortality - burial Lamaštu - stillbirth

\footnotetext{
* A version of this paper was presented at the "Life at the Margins: Questions in Ancient Near Eastern Social History" workshop, co-organized by the author and J. Nicholas Reid; the workshop was held at New York University's Institute for the Study of the Ancient World on 17 April, 2015, and was generously funded by ISAW. The present version of this paper has benefited greatly from the observations of three anonymous reviewers, to whom I extend my gratitude. I dedicate this research to the memory of my son, Jonah Enkidu Valk, ז"ל.
} 


\section{Introduction}

In the developed world today, infancy is not generally associated with mortality. This has not always been the case. The process that leads from conception through development in utero to life outside the womb is fraught with difficulties and affords ample opportunity for complication. Sometimes, these complications - be they congenital, related to illness, related to malnutrition, or arising from some other factor or combination of factors-result in death. Infant loss was a familiar phenomenon in ancient Mesopotamia (c. 3000-500 BCE ), ${ }^{1}$ and it has left clear traces in the region's surviving archaeological and textual record. But what can be said about this phenomenon? What can we know about how the phenomenon was understood and how it was endured? It is the aim of this study to address these questions. Before proceeding to an analysis of the available material and textual data from ancient Mesopotamia, I shall survey research from various disciplines to establish an appropriate interpretative framework. This approach assumes that human beings are essentially alike, even if their cultures differ. As Markham Geller asserts, "there is no reason to assume that the Mesopotamians had an entirely different psychological make-up from modern Europeans."2 In the same vein, there is no reason to assume that ancient Mesopotamians had an entirely different experience of infant loss from people in other societies.

For the sake of terminological clarity, it is first necessary to define what precisely is meant by the term 'infant'. Here, an infant is defined as one who has reached the stage of viability within the womb (at roughly 7 months' gestation), up to and including the end of the first year of life outside of the womb. ${ }^{3}$ This definition is deliberately loose. Given that individual infants develop at varying rates, it is not useful to set overly strict parameters. The inclusion of viable foetuses within the 'infant' rubric further serves to ensure that stillbirth is integrated into the broader discussion presented here, as there is no rigid

1 These dates are intended as an approximate delineation of the chronological scope of this paper, and correspond roughly to the period during which cuneiform was the primary medium for writing in Mesopotamia. The term Mesopotamia is similarly intended as a loose geographic designation for the alluvial plains of the Tigris and Euphrates, along with adjacent areas. Of course, not every period and place within this geographic and temporal range is equally productive in terms of evidence for this study.

2 M.J. Geller, "Freud, Magic and Mesopotamia: How the Magic Works." Folklore 108 (1997): 5.

3 For seven months as a marker of viability in antiquity, see M. Stol, Birth in Babylonia and the Bible: Its Mediterranean Setting (Groningen: Styx, 2000): 20-23. Restricting the definition of infancy to the first year of life ex utero correlates loosely to the development of mobility; the World Health Organization also defines infant mortality as the death of infants before their first birthday. 
distinction between responses to stillbirth and responses to infant death after mere minutes, hours, or days following birth. ${ }^{4}$ Defining infants loosely also serves a more practical purpose: it is difficult and often impossible to identify the age in months of an infant on the basis of archaeological excavation reports, which do not use uniform criteria in their evaluation of human remains and sometimes lack serious osteological analyses. ${ }^{5}$ It is also not always possible to determine the approximate age or precise life-stage of individuals on the basis of the terminology used to refer to them in the ancient Mesopotamian textual record, as many of the relevant terms have a range of ambiguity that is comparable to that of contemporary English language designations like 'baby', 'infant', and the vaguer 'little one'.

Beyond the Parental Indifference Hypothesis

Although it is impossible to reconstruct with certainty for any ancient time and place, the rate of infant mortality in the pre-modern period has recently been estimated to lie in the $20 \%$-to- $30 \%$ range, though data from early 19 th-century France suggests that a rate as low as $10 \%$ may have been possible under certain circumstances. ${ }^{6}$ In pre-modern societies, the rate of stillbirth has probably hovered at or around $5 \% .^{7}$ Accordingly, in pre-modern societies and in antiquity more generally, roughly 1 in 5 infants will not have survived into childhood. It is impossible to know whether this number should be adjusted upward or

4 This is not to suggest that stillborn infants and infants who survive ex utero for months are congruent or were perceived as such, but merely to ensure as full a coverage of infant loss as possible. There is no immediate reason to differentiate strictly between stillborn infants and infants who survive ex utero for months on the basis of the available Mesopotamian evidence. See also fn. 25 .

5 This problem is particularly acute with older excavations in Mesopotamia, as many of them were undertaken before the development of sophisticated methods of osteological investigation. For recent advances in the determination of the age of death of infants in antiquity, see S. Hillson, "The World's Largest Infant Cemetery and Its Potential for Studying Growth and Development." Hesperia Supplements 43 (2009): 143-152.

6 These figures relate to mortality in the first year of life: R. Woods, Children Remembered: Responses to Untimely Death in the Past (Liverpool: Liverpool University Press, 2006):Chapter 3; see pp. 42-43 for the data from France. See also R. Woods, "Ancient and Early Modern Mortality: Experience and Understanding." The Economic History Review 6o/2 (2007): 385 .

7 For an analysis of this figure, see Chapter 4 in R. Woods, Death before Birth: Fetal Health and Mortality in Historical Perspective (New York: Oxford University Press, 2009). See Woods, Children Remembered: 51-52, for data regarding the consistent rate of stillbirth of about $5 \%$ in England and Wales from the 16th century through to the end of the 2oth century. 
downward for ancient Mesopotamia. Either way, the figure remains very high: infant loss was an inescapable fact of life. As Tim Parkin has written in relation to classical antiquity, "this was a young world where death was a constant and visible reality ... In fact, the majority of deaths in an ancient society were probably of infants and very young children." ${ }^{8}$

The prevalence of infant loss in antiquity has led some scholars to posit varying iterations of what Robert Woods has labelled the 'parental indifference hypothesis', which postulates that "parental indifference and childhood mortality are positively and significantly related." ${ }^{\prime \prime}$ In other words, where infant mortality rates are high, the emotional investment in infants and the consequent grief at their passing will be correspondingly low. The parental indifference hypothesis has not been articulated explicitly in ancient Mesopotamian scholarship—not least because research on infants in ancient Mesopotamia is still in its infancy, so that the subject has not yet received much scholarly attention. It has, nevertheless, been aired widely in studies of various pre-modern and ancient societies and can therefore be considered an appropriate point of departure for a consideration of the Mesopotamian evidence, even if only to challenge its applicability.

Perhaps the first proponent of the parental indifference hypothesis was the French historian Philippe Ariès, who argues with reference to infants in L'enfant et la vie familiale sous l'Ancien Régime that in the pre-modern period "people could not allow themselves to become too attached to something that was regarded as a probable loss." ${ }^{10}$ This position is echoed by the noted classical scholar Moses Finley, who writes that "in a world in which such early deaths and burials were routine, so to speak, the intensity and duration of the emotional responses were unlike modern reactions."11 More provocative statements of this view have been formulated by other scholars. Lawrence Stone contends that "the omnipresence of death coloured affective relations at all levels of society, by reducing the amount of emotional capital available for prudent investment in any single individual, especially in such ephemeral creatures as infants," and that "it was very rash for parents to get too emotionally

T. Parkin, "The Demography of Infancy and Early Childhood in the Ancient World." In The Oxford Handbook of Childhood and Education in the Classical World, ed. J. Evans Grubbs and T. Parkin (New York: Oxford University Press, 2013): 46.

10 From the English translation: P. Ariès, Centuries of Childhood (London: Penguin, 1973): 37.

11 M.I. Finley, "The Elderly in Classical Antiquity." Greece \& Rome 28/2 (1981): 159. 
concerned about creatures whose expectation of life was so very low."12 Edward Shorter adopts a comparable position, maintaining with regard to the premodern world that "in traditional society, mothers viewed the development and happiness of infants younger than two with indifference."13 Shorter also goes further, inverting the standard presentation of the parental indifference hypothesis by arguing that disinterest in infants is not a product of high infant mortality rates, but rather their cause: "the high rate of infant loss is not a sufficient explanation for the traditional lack of maternal love because precisely this lack of care was responsible for the high mortality... The point is that these mothers did not care, and that is why their children vanished in the ghastly slaughter of the innocents that was traditional child-rearing." ${ }^{14}$

The parental indifference hypothesis has numerous shortcomings that apply transculturally. For one, even if there is a general awareness that infants have a high likelihood of dying before their first birthday, this does not mean that individual caregivers will expect their own infants to die. The statistical odds of infant death in high-infant-mortality societies are generally less than one in two, and usually significantly less, so that expecting an average infant to perish does not reflect their actual probability of dying. Whatever the statistical soundness of expecting infant death, the ubiquity of the optimism bias - which leads people to believe that bad things are more likely to happen to other people-suggests that many caregivers will in any case assume that somebody else's infants will be the ones to perish rather than their own. ${ }^{15}$ High infant mortality rates do not, therefore, translate into a general expectation that one's own infants will fall victim to an early death.

Further, rare indeed are parents who are able to distance themselves emotionally from their infant children due to a heightened likelihood of their dying; and how unfortunate for those little ones, so totally dependent on the goodwill and affection of those who care for them, to be reared by people who refuse to bond with them because - to paraphrase Lawrence Stone-they are investing their emotional capital prudently. This is a difficult argument to accept in light of the continuous contact that binds infants to their caregivers, who must devote a great deal of time, attention, and energy to them if they are to stand much of a chance of surviving at all. In such circumstances, it is reasonable to expect that in most cases bonds will form between infant

\footnotetext{
12 L. Stone, The Family, Sex and Marriage in England 1500-1800 (New York: Harper \& Row, 1977): $65^{1-652}$ and 70 .

13 E. Shorter, The Making of the Modern Family (New York: Basic Books, 1975): 168.

14 Ibid.: 203-204.

15 See T. Sharot, “The Optimism Bias." Current Biology 21/23 (2011).
} 
and caregiver regardless of the former's likelihood of a premature death. This expectation appears to be confirmed by recent research into the biology of mother-infant bonding, which indicates that there are (involuntary) processes at work in the human body that serve to form close bonds between infants and caregivers, which would apply irrespective of the historical and social context. ${ }^{16}$

I am far from alone in my reservations about the parental indifference hypothesis. One of the more effective critiques has been voiced by Linda Pollock, who demonstrates with reference to 16th- through 19th-century Europe that the main arguments marshalled in favour of the parental indifference hypothesis "are at best only applicable to a minority of parents and children" and that "nearly all children were wanted, such developmental stages as weaning and teething aroused interest and concern and parents revealed anxiety and distress at the illness or death of a child."17 Mark Golden has similarly challenged the parental indifference hypothesis in the classical context, notably in his 1988 article "Did the Ancients Care when their Children Died?" Golden refers to the readily observable grief at the death of children and infants that is documented in a range of classical sources; Golden is, however, careful to note that although unambiguous tendencies toward mourning infant loss are apparent in the classical world, it is also clear that there was variation and "that some citizens were otherwise reluctant to raise any or many children. This contradiction may merely confirm that on this issue as on others public opinion was not uniform."18

16 For the evolutionary origins of such processes, see K.D. Broad, J.P. Curley, and E.B. Keverne, "Mother-Infant Bonding and the Evolution of Mammalian Social Relationships." Philosophical Transactions: Biological Sciences 361.1476 (2006). The biology of bonding is mediated by the hormone oxytocin. For its role in developing mother-infant and caregiver-infant bonds, see M. Galbally et al, "The Role of Oxytocin in Mother-Infant Relations: A Systematic Review of Human Studies." Harvard Review of Psychiatry 19/1 (2011), I. Gordon et al, "Oxytocin and the Development of Parenting in Humans." Biological Psychiatry 68/4 (2010), and M. Nagasawa, "Oxytocin and Mutual Communication in Mother-Infant Bonding." Frontiers in Human Neuroscience 6/31 (2012).

17 L.A. Pollock, Forgotten Children: Parent-Child Relations from 1500 to 1900 (Cambridge: Cambridge University Press, 1983): 267; 268. See also p. 271 for a scathing assessment: "The material analysed here does not support the evolutionary theories on the history of childhood ... there is no dramatic transformation in child-rearing practices in the 18 th century. It is a myth brought about by over-hasty reading, a burning desire to find material to support the thesis and a wilful misinterpretation of evidence."

18 M. Golden, "Did the Ancients Care when their Children Died?" Greece \& Rome 35/2 (1988): 153 . 
Golden hits upon a key point: we should not expect responses to infant loss to be universal. Every individual is different, and it is therefore impossible to state that all parents and caregivers were committed to the wellbeing of infants even if the overwhelming majority were. ${ }^{19}$ This is equally true today, where news cycles are punctuated by stories of severe child abuse and neglect, attesting to the fact that children are not always welcome or treated with particular care and tenderness. In this light, it should be unsurprising to observe that abuse and neglect of infants, along with the attitudes that inform them, were also present in ancient societies. The argument, then, pertains to the extent to which these attitudes prevailed in antiquity. A more nuanced formulation of the parental indifference hypothesis would maintain that high infant mortality - as it existed in ancient societies - is positively correlated with attitudes that foster abuse and neglect of infants, either as their cause or as their product. But is this position tenable, and is it a useful prism through which to understand the Mesopotamian evidence?

\subsection{Infants in Traditional Societies}

Textual production in ancient societies does not offer a comprehensive or representative sampling of attitudes to infants. There are no treatises from the ancient world entitled "Infants: what we think about them and how we feel when they die". Even if such texts did exist, they, like the great majority of ancient texts, would have been the product of elite male writers in societies where caring for and dealing with infants was largely woman's work-a female preserve that incorporated mourning for the passing of infants. ${ }^{20}$ Accordingly, any such treatise would likely offer a subjective and limited insight into the attitudes and feelings of precisely those members of society who were chiefly responsible for the wellbeing of infants and upon whom infants depended, namely women. The texts that do survive from ancient Mesopotamia do not reflect systematically or at any great length on infants and how people relate to them or to their passing; at best, they offer vignettes, glimpses, and observations of such attitudes. Archaeological evidence is equally problematic, as its interpretation is rarely unambiguous and conclusions regarding its significance

\footnotetext{
19 Cf. E. Scott, The Archaeology of Infancy and Infant Death (Oxford: Archaeopress, 1999): 125: "despite the generalities, there is no universal response to the infant."

20 For childcare as women's work in ancient Israel, see C. Meyers, Rediscovering Eve: Ancient Israelite Women in Context (New York: Oxford University Press, 2013): 136-139. For the specific association of women with mourning in classical antiquity, see M. Golden, "Mortality, Mourning and Mothers." In Naissance et petite enfance dans l'Antiquité, ed. V. Dasen (Fribourg: Academic Press Fribourg, 2004): 156.
} 
are often tentative and provisional. Given the deficiencies of the available evidence, it is essential to approach the Mesopotamian data on the basis of comparative research. In this light, a brief foray into the realm of anthropological and ethnographic findings constitutes a useful starting point and an invaluable platform on which to build.

Contrary to the parental indifference hypothesis, anthropologist Robert LeVine concludes in his survey of research into childrearing practices that "in populations with high infant mortality rates, parents will have the physical survival and health of the child as their overriding conscious concern, particularly in the early years, and child-rearing customs will reflect this priority."21 This is in line with current research into childrearing practices in populations of hunter-gatherers, which finds that infants receive continuous care and attention, primarily from their mothers. ${ }^{22}$ As a mode of childrearing, a focus on the wellbeing of the infant is evident in traditional societies more broadly. ${ }^{23}$ A particularly evocative description of what this type of childrearing might look like is narrated by the anthropologist J.K. Campbell in his study of an isolated and traditional community of Sarakatsan shepherds in Greece in the first half of the 2oth century. It is worth reproducing at length:

Children from the day of their birth are the centre of attention and interest in the family. The needs of the infant take priority over all others. Since the family generally lives in a single hut without internal partitions, the adults

21 R.A. LeVine, "Child Rearing as Cultural Adaptation." In Culture and Infancy: Variations in the Human Experience, ed. P.H. Leiderman, S.R. Tulkin, and A. Rosenfeld (New York: Academic Press, 1977): 21.

22 See for instance M. Konner, "Hunter-Gatherer Infancy and Childhood: The !Kung and Others." In Hunter-Gatherer Childhoods: Evolutionary, Developmental and Cultural Perspectives, ed. B.S. Hewlett and M.E. Lamb (New Brunswick: Transaction Publishers, 2005), and, in the same volume, A. Hirasawa, "Infant Care among the Sedentarized Baka Hunter-Gatherers in Southeastern Cameroon."

23 Pace D.F. Lancy, “'Babies Aren't Persons': A Survey of Delayed Personhood.” In Different Faces of Attachment: Cultural Variations of a Universal Human Need, ed. H. Otto and H. Keller (Cambridge: Cambridge University Press, 2014). The examples enumerated by Lancy bespeak variation in the social status of and social attitudes to infants; they do not controvert the notion - and in fact by and large underscore it - that in general parents strive to ensure the best possible outcomes for their offspring, even if there is no unanimity regarding what this outcome might be and how best to achieve it. There is also a clear difference between social attitudes aimed at easing or suppressing the pain of losing infants and the biological realities informing such pain-for which see fn. 16 above and section 1.2 below. 
must make many concessions... Mothers are fearful of the effects of cold air and evil spirits, and even at the height of summer a fire is kept burning day and night inside the hut to the discomfiture of the adults. If the child is a light sleeper, nobody is allowed to talk. For the first forty days after the birth, the hut or house after dusk is like a city under siege, with windows boarded, the door barred, and salt and incense at strategic points such as the threshold and window cracks to repel any invasion of the Devil. The child is the single concern, and almost the only topic of conversation. From its earliest days the infant receives attention from all members of the family. The grandmother nurses it while her daughter-in-law moves about her many tasks. When he returns from the sheep the father at once turns to his child and plays with it. The grandfather, the uncles, and the unmarried aunts are always bending over the cradle to smile at it, and young siblings, ignoring the child's resentment, plant enormous kisses on its face. This intense attitude of love and concern for the child on the part of all the members of the extended family does not change as the child grows up. ${ }^{24}$

This description is the very opposite of the parental indifference hypothesis. It demonstrates that at least among the Sarakatsan-as appears to be true also for other pre-modern societies that have been subject to anthropological investigation - parents, and particularly mothers, are anything but indifferent to their offspring. The threat of infant loss is recognized, active steps are taken to combat and minimize it, and there is no discernible decline in affection for and attachment to infants, but rather the reverse. These actions bespeak parental interest, not indifference.

The studies referred to above are, however, only part of the picture. They relate to small-scale societies that might not be representative of the urban life that was a salient feature of the ancient Mesopotamian social landscape and of other pre-modern times and places. Nevertheless, the attitudes of parents surveyed by Linda Pollock in much more urban European environments between 1500 and 1900 appear not to have been altogether different, and Pollock observes that "the vast majority of writers through the centuries were extremely distressed at the death of a child, irrespective of their class, sex or

24 J.K. Campbell, Honour, Family and Patronage: A Study of Institutions and Moral Values in a Greek Mountain Community (Oxford: Clarendon Press, 1967): 154. Note the essential similarity between the measures taken to ward off infant loss in this passage and some of the measures undertaken by ancient Mesopotamians, particularly in relation to warding off Lamaštu, for which see section $3 \cdot 3$ below. 
religion and no matter at what age the child died." ${ }^{25}$ Comparative studies of mother-infant relationships in contemporary societies have noted that despite significant cultural variation, differences in the nature and quality of motherinfant relationships between societies are not pronounced. ${ }^{26}$ This is true also in cases where one society can be regarded as 'modern' and the other as 'traditional', in the sense of having undergone the social transformations that are considered the hallmark of modernity or not.

Rather than differences between cultures, it is actually differences in motherinfant relationships within cultures that are sometimes more readily apparent. In their study of maternal attitudes and maternal behaviour, Howard Moss and Sandra Jones conclude that "even in seemingly homogenous samples, there may be subgroups that differ as to family values, social structure, and style of functioning. Comparisons among these subgroups can provide results that are as striking and as informative as those observed among phenotypically more divergent groups." ${ }^{27}$ On the strength of the evidence presented above, it should be apparent that there is a significant degree of universality in the treatment of infants across human societies. The notion that there is a fundamental distinction between pre-modern and modern ways of relating to infants appears to be misplaced, as does the parental indifference hypothesis that is its theoretical

25 Pollock, Forgotten Children: 141. Pollock notes that "it does appear that, in every century studied, young infants were not mourned as deeply as older children," but this is not unexpected given the much briefer time available for the development of close bonds between infants and caregivers. It also expressly does not mean that there was no mourning for the passing of young infants, but rather that such mourning was in general less intense than the mourning experienced at the loss of older children.

26 See M.D.S. Ainsworth, "Infant Development and Mother-Infant Interaction Among Ganda and American Families." In Culture and Infancy: Variations in the Human Experience, ed. P.H. Leiderman, S.R. Tulkin, and A. Rosenfeld (New York: Academic Press, 1977): 125: "I was very much more impressed by the similarities between the two samples than by their differences." See also M. Lewis and P. Ban, "Variance and Invariance in the MotherInfant Interaction: A Cross-Cultural Study." In Culture and Infancy: Variations in the Human Experience, ed. P.H. Leiderman, S.R. Tulkin, and A. Rosenfeld (New York: Academic Press, 1977): 351: "There is remarkably little difference between the behaviour of our two samples of American and Yugoslavian dyads. This is in spite of the fact that the demographic description would lead one to conclude that large differences exist between the worlds of the Yugoslavian and American infants. This is rather remarkable, when one considers the seemingly all-pervasive differences between the cultures (and subcultures)."

27 H.A. Moss and S.J. Jones, "Relations Between Maternal Attitudes and Maternal Behavior As a Function of Social Class." In Culture and Infancy: Variations in the Human Experience, ed. P.H. Leiderman, S.R. Tulkin, and A. Rosenfeld (New York: Academic Press, 1977): 464. 
expression. ${ }^{28}$ There is not nearly as much of a contrast between modern and pre-modern attitudes toward infants in practice as might be supposed, despite immense differences in cultural and social conditioning, ${ }^{29}$ there is instead significant variation among individual caregivers within societies that arises from the individual dispositions of these caregivers. ${ }^{30}$

\subsection{Grief in the Animal Kingdom}

One budding area of scientific research offers an invaluable parallel to and reinforces the probable biological foundation for these conclusions, namely the field of animal emotion. ${ }^{31}$ The notion that animals have rich emotional livesan idea taken for granted by Charles Darwin, who penned a book entitled The Expression of the Emotions in Man and Animals - is gaining increasing traction among researchers. A humorous (and perhaps anthropomorphizing) example of simian emotion is reported by psychologist Marc Hauser, who "once

28 This is not to say that there are no differences in such attitudes, but merely to point out that we should not imagine that infants are ever totally disregarded-particularly in view of the strong transcultural continuities that comparative research reveals. Nevertheless, there are differences in some of the ideological justifications for reproduction; for a study that examines attitudes to reproduction in biblical Israel, see L.W. Koepf-Taylor, Give Me Children or I shall Die: Children and Communal Survival in Biblical Literature (Minneapolis: Fortress Press, 2013).

29 Perhaps the most compelling evidence of the importance of cultural and social conditioning is the practice of female infanticide, attested in many times and places but particularly well documented among Inuit peoples and in India. For the former, see A. Balikci, "Female Infanticide on the Arctic Coast." Man 2.4 (1967), and for the latter see R.S. Freed and S.A. Freed, "Beliefs and Practices Resulting in Female Deaths and Fewer Females than Males in India." Population and Environment 10/3 (1989). Even at its most extensive, female infanticide is restricted to small minorities of infants and does not controvert the general argument presented here. For an examination of the possible causes of female infanticide, see K. Hawkes, "A Third Explanation for Female Infanticide." Human Ecology 9/1 (1981).

30 See Ainsworth, "Infant Development and Mother-Infant Interaction": 125: "I was impressed with the wide range of individual differences within each sample." See also Pollock, Forgotten Children: 270: "It is difficult to formulate any one theory of parental care in the past - there was a great deal of individual variation... The sources reveal that there is little, if any, connection between [parental] attitudes and behaviour;" cf. p. 271: "However, despite the individual differences in child-rearing techniques, there are limits on variation. These limits are the dependency of the child and the acceptance of the responsibility for the protection and socialisation of that child by the parents."

$31 \quad$ For a recent example, see C. Safina, Beyond Words: What Animals Think and Feel (New York: Henry Holt, 2015). 
surreptitiously observed a male rhesus monkey that, after copulating with a female, paraded around - until he tripped over an uneven patch of flooring and fell down. The monkey immediately and anxiously looked around before he got up-seemingly embarrassed about his stumble. Only when he was sure that no one had seen him did he get up and strut off-with his back straight and head held high — as if nothing had happened."32

More pertinent for the present purposes is the recent work by anthropologist Barbara King on mourning among animals. King's research indicates that "a broad range of species-including some quite distantly related to humans-lament the passing of loved ones." ${ }^{33}$ Mourning of this kind is particularly discernible in the grieving of mothers over their deceased infants. The identification of grief behaviours in wide swathes of the animal kingdom contradicts the 'null hypothesis', which is the biologist's equivalent of the parental indifference hypothesis and maintains that "wild animals faced with the challenges of survival and reproduction should not expend time or energy on the expression of grief when a group member dies." ${ }^{44}$ King argues instead that:

because death and mourning surely count as one of life's most stressful events, there may be a common biological underpinning to the grief that animals - horses, goats, rabbits, cats, dogs, elephants, chimpanzees, and people-feel. To make this suggestion is not to say that we are hard-wired creatures whose brains all respond in identical ways. It is, rather, to take seriously the notion that we mammals share some tendencies in our biology and in the ways our life experiences may affect our biology. Though based on that common platform, outcomes will-because of species-specific behaviours, different developmental histories, and individual personalities in complex combination - be variable, both across and within species. ${ }^{35}$

In line with the conclusions presented above about the significance of differences in mother-infant relationships within cultures, King notes that "in each species I find a grief continuum, with some individuals seeming indifferent to a companion's death and other individuals appearing distraught over such a

32 K. Wilhelm, “Do Animals Have Feelings?” Scientific American Mind 17 (2006): 29.

33 B.J. King, "When Animals Mourn." Scientific American 309 (2013): 64.

34 B.J. King, How Animals Grieve (Chicago: University of Chicago Press, 2013): 65.

35 Ibid.: 50. See also p. 7 on mourning among humans: "It's no use trying to predict how an individual will react to losing a relative or some other person who has played a role in her life. People may not grieve when someone close to them dies. Or they may grieve in an interior way, invisible to others, or only when alone."

JESHO 59 (2016) 695-749 
loss,"36 and that "caring, competent mothers exist side by side with indifferent, neglectful mothers among our closest living relatives_-indeed, within our own species." ${ }^{37}$

The important insight from King's work is that grief and mourning over the passing of others-and in our case notably over the passing of infants-are a common response not only in humans, but also in a whole host of species, suggesting that this is a biological disposition inherent both to humans and to other animals. Further, such responses, even though they are common, are not universal, and different individuals will respond differently to loss in different circumstances. Empirical evidence from the animal kingdom and from the human world indicates that parents are in general attached to their offspring and that the passing of infants will be met with grief, regardless of whether or not the human society in question is modern or ancient, rural or urban, settled or mobile. ${ }^{38}$ Neither the parental indifference hypothesis nor a more nuanced reformulation of it can be regarded as tenable: parents are rarely indifferent to their infant children, and they tend to grieve for them when they die. This conclusion-drawn as it is from a range of comparative and interdisciplinary evidence-establishes a secure framework from which to interpret the available data regarding responses to infant loss in ancient Mesopotamia.

\section{Infants in the Ancient Mesopotamian Archaeological Record}

Infants are difficult to detect in the archaeological record. They do not fashion pots, they do not make tools, and they do not build houses. The only objects outside of funerary contexts that can be associated with them are toys, and the identification of objects as toys or their assignment to particular age groups is rarely unambiguous. ${ }^{39}$ To the extent that objects can be identified as infant toys, ${ }^{40}$ their existence demonstrates that effort was taken to supply at least

36 B.J. King, "When Animals Mourn": 67.

37 B.J. King, How Animals Grieve: 36 . For a brief survey of grief among animals in the context of a study of grief among humans, see J. Archer, The Nature of Grief: The Evolution and Psychology of Reactions to Loss (London: Routledge, 1999): 45-63, and especially pp. 53-56.

38 See Woods, Children Remembered: 212: "Historical societies were made up of people with varying capacities to be loving parents living in material conditions that militated against the possibility of providing good-quality care."

39 See S. Crawford, "The Archaeology of Play Things: Theorising a Toy Stage in the 'Biography' of Objects." Childhood in the Past 2 (2009).

40 See A. Draffkorn Kilmer, "Games and Toys in Ancient Mesopotamia." In Actes du XII ${ }^{e}$ Congrès International des Sciences Préhistoriques et Protohistoriques, ed. J. Pavúk (Bratislava: Institut Archeologique de l'Academie Slovaque des Sciences, 1993). 
some infants with items that would interest and amuse them, and this effort in turn implies an interest in and concern for the emotional wellbeing of infants.

In ancient Mesopotamian art children and infants are rarely represented. When infants are depicted they are invariably being held or carried by women, and sometimes they are shown suckling. ${ }^{41}$ Mesopotamian infants do not appear to figure in art independently of female caregivers, suggesting that they were seldom thought of without reference to their mothers or to alternate female caregivers, upon whom they depended for survival. The intimate relationship between infants and maternal women conveyed in these representations is indicative of the general closeness of mother-infant bonds and points to attachment between maternal women and infants. It is possible to infer that women who were attached to their infant wards would generally find the death of these infants to be a source of grief, but little more can currently be said about infant loss in ancient Mesopotamia on the basis of Mesopotamian art.

Beyond toys and art, archaeological evidence regarding infants is largely limited to material from infant burials, which comprise the physical remains of infants, the objects recovered alongside them, and the broader archaeological contexts of the burials themselves. Here, the body of material is expansive. Infant burials are attested throughout ancient Mesopotamia, surfacing in most archaeological excavations. Given the high infant mortality rate, the apparent omnipresence of infant burials is entirely expected. Generally speaking, two clear trends emerge from an investigation of the aggregated evidence

41 The motif of a woman with an infant is common in Mesopotamian artistic representation; for an introduction, see Z. Bahrani, Women of Babylon: Gender and Representation in Mesopotamia (New York: Routledge, 2001): 81-82, and S.L. Budin, Images of Woman and Child from the Bronze Age: Reconsidering Fertility, Maternity, and Gender in the Ancient World (New York: Cambridge University Press, 2011): Chapter 4. Budin argues that Old Babylonian plaques depicting women with infants have an apotropaic function. For motherhood and childcare as fundamental to womanhood in Neo-Assyrian reliefs, see P. Albenda, "Woman, Child, and Family: Their Imagery in Assyrian Art." In La Femme dans le Proche-Orient antique, ed. J.-M. Durand (Paris: Editions Recherche sur les Civilisations, 1987): 19. For examples of depictions of women with infants and children on seals, see C.E. Suter, "Who are the Women in Mesopotamian Art from ca. 2334-1763 BCE?" Kaskal 5 (2008): 22. For depictions of women with infants on third and second millennium terracotta plaques, see S.B. Graff, "Sexuality, Reproduction and Gender in Terracotta Plaques from the Late Third-Early Second Millennia BCE." In Critical Approaches to Ancient Near Eastern Art, ed. B.A. Brown and M.H. Feldman (Berlin: De Gruyter, 2014): 372-374, and Figure 2 on p. 375 . 
concerning ancient Mesopotamian infant burials: a propensity for intramural burial and a propensity for jar burial. ${ }^{42}$

\subsection{Intramural Burial}

While infant burials are frequently encountered during the course of archaeological excavations, their distribution differs markedly from that of adults. Infants are notable for their underrepresentation in designated cemeteries and are simultaneously overrepresented in domestic inhumations. ${ }^{43}$ This distribution is by no means exclusive. Infants are sometimes found in cemeteries and adults are sometimes buried intramurally, such that there is likely to be a range of burial practices at any given time and place. ${ }^{44}$ Even so, the division in burial practices for infants and for adults is occasionally stark, as it is in one area in Middle Babylonian Nippur, where a number of infant burials were recovered in the inner rooms of domestic structures in Level II I while no intramural adult burials were recorded there at all. ${ }^{45}$ Likewise, in Nuzi many infants were found buried within domestic structures, but no adults were. ${ }^{46}$ In places where both adults and infants were buried intramurally, there nevertheless appears to be some differentiation in the location of such burials. In Old Babylonian Ur,

42 Stillborn infants in particular may also have been buried in designated areas within temples associated with the goddesses Gula and Inanna, though no such burial areas have yet been confirmed archaeologically; if so, it is not clear what the significance of such burial might be, though it seems reasonable to connect it in some way to Gula's healing function. See most recently, B. Böck, The Healing Goddess Gula: Toward an Understanding of Ancient Babylonian Medicine (Leiden: Brill): 32, 44.

43 Underrepresentation of infants in cemeteries is likely attributable in part to the rapid rate of deterioration of the physical remains of infants compared to those of more mature individuals; see H. Guy, C. Masset, and C. Baud, "Infant Taphonomy." International Journal of Osteoarchaeology 7 (1997). There is also a further problem stemming from the fact that ancient Mesopotamian cemeteries have not generally been the focus of excavation and analysis, so that current impressions could prove to be based on misleading data. The overrepresentation of infants in domestic burials is complicated by the fact that the date of such burials is not always identifiable with certainty, as the archaeological levels from which they are retrieved are sometimes disturbed.

44 See for instance H. Baker, "Neo-Babylonian Burials Revisited." In The Archaeology of Death in the Ancient Near East, ed. S. Campbell and A. Green (Oxbow: Oxford, 1995): 218. For more on intramural burial, see L. Battini-Villard, L'espace domestique en Mésopotamie de la IIIe dynastie d'Ur à l'époque paléo-babylonienne (Archaeopress: Oxford, 1999).

45 R.L. Zettler, Nippur III: Kassite Buildings in Area WC-1 (Chicago: Oriental Institute, 1993): 39 .

46 R.F.S. Starr, Nuzi: Report on the Excavations at Yorgan Tepa near Kirkuk, Iraq: Volume I, Text (Cambridge: Harvard University Press, 1939): 348-357. 
individuals of all age groups are buried inside domestic buildings, but infants are clustered together in secluded inner rooms near the structures identified as domestic chapels, an area from which adults are generally absent; ${ }^{47}$ in wellpreserved houses, a select infant was found buried before the domestic chapel in such a way that the vessel in which the infant was placed remained visible. ${ }^{48}$

There are interesting parallels for the intramural inhumation of infants in ancient Mesopotamia. The practice of intramural burial of infants is attested throughout the ancient Near East and the Eastern Mediterranean in the millennia before the Common Era, and in many sites the contrast between intramural infant burial and the burial of adults in cemeteries is evident. ${ }^{49}$ Intramural burial is a prehistoric practice, which has been documented extensively at the 7th-millennium Anatolian site Çatalhöyük. ${ }^{50}$ For the period covering roughly 5400-4400 BCE in Mesopotamia, Gareth Brereton observes a sharp distinction between intramural infant burials and extramural adult burials. ${ }^{51}$ Much further afield, Alison Moore notes that "the exclusion of premature and neonatal infants from formalised cemetery contexts and their burial within non-formal domestic and settlement contexts is a common feature of the Romano-British archaeological record." 52 Intramural infant burial, then, is a phenomenon by no means unique to ancient Mesopotamia.

Despite the geographic and temporal spread of intramural infant burial there is no consensus regarding its significance. Estelle Orrelle suggests that the burial of infants in liminal contexts, which in her analysis include intramural

47 Hafford, Brad. "Ur Digitization Project: June 2014." Published June 23, 2014, at http://www .penn.museum/blog/museum/ur-digitization-project-june-2014/, accessed on April 6, 2015 .

48 L. Woolley and M. Mallowan, Ur Excavations, Volume VII: The Old Babylonian Period (London: The Trustees of the British Museum and the University Museum, Philadelphia, 1976): 30, 34 .

49 See P.J.P. McGeorge, "Intramural Infant Burials in the Aegean Bronze Age." In zèmes Rencontres d'archéologie de l'IFEA: Le Mort dans la ville. Pratiques, contextes et impacts des inhumations intra-muros en Anatolie, ed. O. Henry (Istanbul: IFEA-Ege yayınları, 2011), and K. Birney and B.R. Doak, "Funerary Iconography on an Infant Burial Jar from Ashkelon." Israel Exploration Journal 61 (2011): 34-35.

5o See B. Boz and L.D. Hager, "Living Above the Dead: Intramural Burial Practices at Çatalhöyük." In Humans and landscapes of Çatalhöyük: Reports from the 2000-2008 Seasons, ed. I. Hodder (Los Angeles: Cotsen Institute of Archaeology Press, 2013).

$5^{1} \quad$ G. Brereton, "Cultures of Infancy and Capital Accumulation in Pre-Urban Mesopotamia." World Archaeology 45/2 (2013): 236-237. Note in particular the tables on these pages.

$5^{2}$ A. Moore, "Hearth and Home: The Burial of Infants within Romano-British Domestic Contexts." Childhood in the Past 2 (2009): 33. 
burials, "can be interpreted as an early manifestation of separation of a sacral kind." ${ }^{33}$ The association of intramural infant burial with a sacral dimension is certainly reflected in the burial of infants around domestic chapels in Old Babylonian Ur. For Mercourios Georgiadis, burial of infants within Southern Greek habitation areas in the Early Neolithic is contrasted with the contemporaneous burial of adults in designated external spaces. Georgiadis proposes that this is a result of the symbolic function of infants for the family, in that they represent "a benevolent spirit with protective powers for the household and, possibly, for the community as a whole"54 - and there is evidence of precisely such a spirit in ancient Mesopotamia in the form of the Kübu. ${ }^{55} \mathrm{~A}$ more straightforward interpretation is offered by Kristine Garroway, who notes that "the explanation for burying children under the floor may have been quite simple. It may be that there was an emotional attachment of the family mourning the child's untimely death. Burying the child within the house would then have provided the family with a permanent link between the household and the child." 56

All of these interpretations of intramural infant burial - and others, toocould well be correct, singly or in combination. Indeed, it is most unlikely that any one explanation can account for a practice that is as diffuse as domestic inhumation. It must be kept in mind that although there are pronounced tendencies for intramural infant burial and extramural adult burial, there are no general rules. As Dan Potts asserts concerning ancient Mesopotamia, "there does not seem to have been any 'orthodoxy' when it came to the question of burial within a graveyard as opposed to burial beneath one's house."57 To compound the interpretative challenges, there is no clear textual evidence that helps anchor the practice of intramural infant burial in religio-cultural terms. The provision of funerary offerings to deceased ancestors, as is attested in the performance of the kispu-ritual, might be an appropriate context for

53 E. Orrelle, "Infant Jar Burials-A Ritual Associated with Early Agriculture?" In Babies Reborn: Infant/Child Burials in Pre- and Protohistory, ed. K. Bacvarov (Oxford: Archaeopress, 2008): 75 .

54 M. Georgiadis, "Child Burials in Mesolithic and Neolithic Southern Greece: A Synthesis." Childhood in the Past 4 (2011): 43.

55 For the Kūbu, refer to section 3.4 below.

56 K. Garroway, Children in the Ancient Near Eastern Household (Winona Lake: Eisenbrauns, 2014): 208.

57 D.T. Potts, Mesopotamian Civilization:The Material Foundations (Ithaca: Cornell University Press, 1997): 233 . 
understanding adult intramural burial, but it does not necessarily account for infants and is in any case not dependent on domestic inhumation. ${ }^{58}$

Perhaps the most direct reference to a cultural preference for intramural burial is preserved in Tablet IV of the Epic of Erra and Išum, in which Erra directs his destructive violence against a man who wishes to be buried in his own home:

\section{Erra IV 99-102}

99. ša bìta ìpušu ganūnīma ${ }^{59}$ iqabbi

100. annâ ètepušma apaššaha qerbuššu 101. üm ubtīlanni šimati aṣallal ina libbi

102. šâšu ušmāssuma ušahrab ganūnšu
Whoever has built a house and says: "This is my home!

I have made it; I will be at home in it. On the day fate carries me away, I will sleep within it."

- Him I will cause to die, his home I will lay waste. ${ }^{60}$

In this passage, it appears to be the aspiration of the common man to be buried within his home, where he will 'sleep' after his passing; by thwarting this hope, Erra appears to consign the man in question to a grievous fate. A second passage referring to the propriety of intramural burial is preserved in a Lamaštu incantation, in which the goddess-demon Lamaštu kills an infant and prevents him from being buried in his house: "she did not let him be

$5^{8}$ There is a large literature on ancestor veneration in ancient Mesopotamia. For a useful overview, see J.N. Postgate, Early Mesopotamia: Society and Economy at the Dawn of History (New York: Routledge, 1992): 99-101. Another brief introduction can be found in A. Skaist, "The Ancestor Cult and Succession in Mesopotamia." In Death in Mesopotamia: Papers Read at the XXVI $I^{\mathrm{e}}$ Rencontre assyriologique internationale, ed. B. Alster (Copenhagen: Akademisk Forlag, 1980). For more on the kispu-ritual in the Death in Mesopotamia volume, see also A. Tsukimoto, "Aspekte von kispu(m) als 'Totenbeigabe," and M. Birot, "Fragment de rituel de Mari relatif au kispum."

59 Note the use of the term ganūnu (here translated as "home"), from the Semitic root *gnn. This root yields the meaning of envelopment and the related meanings of garden, sepulcher, and even foetus, all of which can be thought of as enveloped in some way. This web of meaning invites an understanding of the burial of the dead as a return to the womb of mother earth, and functions as a double entendre in the present context: "my home/my tomb". See J. Pasquali, "Symbolique de mort et de renaissance dans les cultes et les rites éblaïtes: 'ga-na-na, les ancêtres et la royauté." Revue d'Assyriologie 107 (2013): 45-48.

6 Erra IV 99-102, in L. Cagni, L'Epopea di Erra (Napoli: Istituto di Studi del Vicino Oriente, 1969): 114-115. 
buried in the house" (ul iddinšu ina bìti ana qebēri). ${ }^{61}$ Instead, Lamaštu commands that the corpse of the deceased infant be abandoned in the wilderness, an act that is contrasted with the ideal of domestic inhumation. These passages tell us little about why infants specifically tended to be buried intramurally. They do, however, intimate that intramural infant burial was unlikely to have been a product of parental indifference or a failure to accord proper funerary rites to the deceased.

On the contrary, burying somebody in their home is a way to root that person eternally in the physical site of that home and in the memory of its inhabitants. ${ }^{62}$ In this light, the intramural burial of infants serves quite literally to incorporate them in the domestic sphere, to tie them to their family homes, and to maintain a physical connection with them; the practice can be contrasted with simply discarding the physical remains of deceased infants and allowing every trace of them to be forgotten. If dead infants were truly unimportant, there is no obvious reason why they might not simply be cast out with the rubbish — as perhaps some were, but very many clearly were not. Intramural infant burial is evidence that care was taken to bury infants in a particular way, though the details of its precise significance remain murky and surely varied across time and space.

\subsection{Jar Burial}

The other propensity evident in ancient Mesopotamian infant burials is the inhumation of infants in ceramic vessels_-jars, specifically_irrespective of the location of the burial. This practice is documented at many sites, ranging from Aššrur ${ }^{63}$ and Nuzi ${ }^{64}$ in the north to Nippur ${ }^{65}$ and $\mathrm{Ur}^{66}$ in the south. Like intramural infant burial, infant jar burial is nonexclusive, so that not every infant at any one site is necessarily buried in a jar even when most or seemingly all are, and neither is the practice always limited to infants even though it often is. Again like intramural infant burial, infant jar burial is by no means limited to Mesopotamia. In sites throughout Bronze Age Canaan, a preponderance of

61 Canonical Lamaštu Series I 158 in W. Farber, Lamaštu: An Edition of the Canonical Series of Lamaštu Incantations and Rituals and Related Texts from the Second and First Millennia B.C. (Winona Lake: Eisenbrauns, 2014): 156-157.

62 At least in theory; in practice, houses could be sold, resulting in a possible rupture between the inhabitants of a house and those buried within.

63 A. Haller, Die Gräber und Grüfte von Assur (Berlin: Verlag Gebr. Mann, 1954): 38.

64 Starr, Nuzi: 348-357.

65 Zettler, Nippur III: 39 .

66 Woolley and Mallowan, Ur Excavations, Volume VII: 34. 
infants are buried in jars. ${ }^{67}$ Krum Bacvarov traces the presence of infant jar burials in southeast Europe to cultural influence from the Neolithic Near East. ${ }^{68}$ At Kylindra on the Aegean island of Astypalaia, an enormous first-millennium BCE infant cemetery has yielded 2,400 infant jar burials. ${ }^{69}$ Inhumation of infants in jars is even documented in medieval Poland, though it is not immediately clear how this practice emerged there..$^{70}$ An example of infant jar burial that certainly constitutes an independent development of the same practice is evident in the Yucatan peninsula in Mexico, where infant inhumation in ceramic jars is well attested centuries before the arrival of Europeans. ${ }^{71}$

There is quite an extensive literature that understands infant jar burial as the return of the deceased infant to a symbolic womb. In this interpretation, the fact that the shape of the jar approximates that of a womb and that infants are often placed inside the jars in a foetal position with their heads toward the opening indicates a conscious effort to mirror the positioning of infants in the womb. ${ }^{72}$ Although such an interpretation is appealing, the problem of uniformity remains: placement of infants in jars is not uniform, so that the jar as womb' explanation is less compelling in those instances and contexts where infant heads are not generally adjacent to the jars' opening. The placement of infants in jars might, moreover, have more to do with the practicalities of inserting infants in jars than with any symbolic or ideological superstructure. Infant heads and shoulders are the broadest parts of their bodies, so that it might be easier for infants to be placed head-last into these vessels. Once the

67 Garroway, Children in the Ancient Near Eastern Household: 221.

68 K. Bacvarov, "A Long Way to the West: Earliest Jar Burials in Southeast Europe and the Near East." In Babies Reborn: Infant/Child Burials in Pre- and Protohistory, ed. K. Bacvarov (Oxford: Archaeopress, 2008).

69 Hillson, "The World's Largest Infant Cemetery": 138-139.

70 L. Gardeła and P. Duma, "Untimely Death: Atypical Burials of Children in Early and Late Medieval Poland." World Archaeology 45/2 (2013): 323-325.

71 E. Pérez de Heredia et al, "Un patrón de entierros infantiles en vasijas durante la transición del Clásico Tardío al Terminal en Chichen Itza, Yucatán.” In XVIII Simposio de Investigaciones Arqueológicas en Guatemala, 2004, ed. J.P. LaPorte, B. Arroyo, and H.E. Mejía (Guatemala: Ministerio de Cultura y Deportes, 2005).

72 For interpretations of burial jars as symbolic wombs, see in particular D. Ilan, "Mortuary Practices at Tel Dan in the Middle Bronze Age: A Reflection of Canaanite Society and Ideology." In The Archaeology of Death in the Ancient Near East, ed. S. Campbell and A. Green (Oxford: Oxbow, 1995): 135, S. Kulemann-Ossen and M. Novák, dKūbu und das 'Kind im Topf'. Altorientalische Forschungen 27 (2000), and Orrelle, "Infant Jar Burials": 73. For the argument that the clay material of burial jars reinforces their function as substitute wombs, see Graff, "Sexuality, Reproduction and Gender": 384 . For the association of a foetal posture of infants in jars with rebirth, see Scott, The Archaeology of Infancy: 105-107. 
body is in the jar, space constraints sometimes dictate that a foetal position is necessary to get the whole of the infant inside without contorting the body. The jar as womb model may therefore be a case of over-interpretation of evidence, at least in some contexts, even if symbolic or ideologically informed explanations subsequently accrued to a practice that developed out of practical considerations. The most straightforward explanation for jar burial-a practice that extends over millennia, across cultures, and even across the Atlantic Ocean-is that many jars happen to be of an ideal shape and size to function as ready-made containers for deceased infants. Still another possibility is that placing infants in jars might be related primarily to apotropaic or hygienic purposes, though these and other categories are of course not mutually exclusive.

Like intramural infant burial, infant jar burial is a widespread and complex phenomenon that defies easy categorization and explanation. The complexity of infant jar burial is illustrated by the Chalcolithic cemetery of Byblos, where 2,097 inhumations were discovered, 2,059 of which were in ceramic vessels. ${ }^{73}$ Remarkably, well over half of these burials were not of infants, and the finds at Byblos demonstrate no age-based variation in burial practices at all. There were also a small number of intramural burials at Chalcolithic Byblos, and these too were equally distributed between adults and non-adults. ${ }^{74}$ Burial practices at Byblos do not align neatly with those attested elsewhere; instead, outwardly identical mortuary traditions are adapted and mediated according to local norms that are impossible to reconstruct with any certainty. This will have been true everywhere, even if the differences are generally less immediately pronounced. By manifesting such an idiosyncratic collection of burial types, Byblos serves as a stark reminder of the variability of burial practices and likely also of the meanings assigned to these practices.

\subsection{Infant Status in Light of Infant Burial}

Intramural infant burial and infant jar burial both indicate an interest in the manner of infant inhumation. The fact that burial practices for infants and adults differ does not necessarily imply that infants were unimportant or not cared for. Indeed, evidence from many individual graves suggests that there is no correlation between differential burial practices and social disregard for

73 G. Artin, "The Jar Burials of the Chalcolithic 'Necropolis' at Byblos." In Babies Reborn: Infant/Child Burials in Pre-and Protohistory, BAR International Series 1832, ed. K. Bacvarov (Oxford: Archaeopress, 2008): 80-82. 
infants. ${ }^{75}$ In one Ubaid-period infant jar burial in Tell Zeidan, dried flowers are deliberately inserted into the ceramic vessel to accompany its occupant. ${ }^{76}$ In Hasanlu, two infants are buried with jewellery and beads comparable in type and quality to that which is interred with adults. ${ }^{77}$ In Nippur, one adult burial includes the placement of some ceramic vessels near the head of the interred individual, presumably to be used in the consumption of food in the netherworld; a contemporaneous infant burial at the same location likewise has ceramic vessels placed by the head of the interred infant, but these vessels are reduced in scale to match the diminutive size of the individual they are intended to serve. ${ }^{78}$ Another infant interred in Nippur is buried with "a string of faience or glass beads" around its neck. ${ }^{79}$ One infant inhumation in Babylon is notable for the wealth of its grave goods, which include ceramic and glass vessels and various items of jewellery that incorporate gold, lapis lazuli, carnelian, and pearls. ${ }^{80}$ These burials underscore the assessment that numerous infants were not simply discarded; there were people who cared enough for them to bury them with unambiguous tokens of concern and attachmentsometimes at considerable expense.

It is important to note in this context that the absence of funerary offerings does not imply the absence of care. The very act of proper burial is in and of itself a sign of the attribution of value to the infant in question. Astrid Lindenlauf observes in the context of ancient Greece that "research at cemeteries such as in Klazomenai suggests that the economic situation of the family played a crucial role in the ways in which the physical remains of humans were disposed of, as here carefully placed child corpses with precious grave goods were found along with those placed in broken ámphorai." ${ }^{\prime 1}$ As in ancient Greece, so surely also in ancient Mesopotamia the relative wealth and the

75 For three examples from northeast Syria, see S. Dunham, "Beads for Babies". Zeitschrift für Assyriologie und Vorderasiatische Archäologie 83 (1993).

76 G.J. Stein, Tell Zeidan. In Oriental Institute Annual Report 2010-2011, ed. G.J. Stein (Chicago: The Oriental Institute, 2011): 137 .

77 M.D. Danti, Hasanlu V: The Late Bronze and Iron I Periods (Philadelphia: University of Pennsylvania Press, 2013): 316.

78 A. McMahon, Nippur V: The Early Dynastic to Akkadian Transition: The Area WF Sounding at Nippur (Chicago: The Oriental Institute, 2006): 39, 70.

79 Ibid.: 56 .

8o Grave 109 in O. Reuther, Die Innenstadt von Babylon (Merkes) (Leipzig: J.C. Hinrichs, 1926): 209-211.

81 A. Lindenlauf, "Thrown Away Like Rubbish—Disposal of the Dead in Ancient Greece." Papers from the Institute of Archaeology 12 (2001): 95. 
relative poverty of some burials will have as much or more to do with the economic circumstances of those doing the burying than with the level of care for the one being buried. The absence of durable grave goods in infant inhumations is by no means equivalent to the absence of affection for these infants.

It is impossible to know if the infant burials that have been recovered in Mesopotamia so far are representative of infant burial practices there tout court. Conceivably, some people did have little regard for infants and did cast their remains out unceremoniously. Infant remains in Mesopotamia have not, however, been identified in contexts that point to disposal of this kind. In 2nd-century вCE Athens, on the other hand, at least 449 infants who appear to have died of natural causes before birth, during birth, or shortly following birth were found deposited in an isolated abandoned well. ${ }^{82}$ While it is tempting to understand the placement of these infants in an abandoned well as a sign of disregard, this is not a necessary corollary. As Maureen Carroll asserts, "public funerary display is not the same as private sentiments of grief." ${ }^{83}$ In situations where for whatever reason infants do not appear to have been accorded anything beyond cursory funerary rites, this can plausibly be attributed to social convention and need not tell us much about how the parents of the deceased infant felt. There is an unmistakable difference between the way cultures can structure and direct outward responses to lived experiences and the emotional impulses felt by the individuals involved. ${ }^{84}$ Insofar as it is possible to draw generalized conclusions from a remarkably diffuse and incomplete body of evidence, the ancient Mesopotamian archaeological record points to the fact that infants were not without social status and that they were mourned when they died. This is entirely consistent with what one might expect to find on anthropological grounds alone.

82 M.A. Liston and S.I. Rotroff. "Babies in the Well: Archeological Evidence for Newborn Disposal in Hellenistic Greece." In The Oxford Handbook of Childhood and Education in the Classical World, ed. J. Evans Grubbs and T. Parkin (New York: Oxford University Press, 2013).

83 M. Carroll, "No Part in Earthly Things'. The Death, Burial and Commemoration of Newborn Children and Infants in Roman Italy." In Families in the Roman and Late Antique World, ed. M. Harlow and L. Larsson Lovén (London: Continuum, 2012): 50.

84 See P.N. Stearns and C.Z. Stearns, "Emotionology: Clarifying the History of Emotions and Emotional Standards." The American Historical Review 90/4 (1985). For a necessary rethinking of the Stearns' ideas, see also B.H. Rosenwein, "Worrying about Emotions in History." The American Historical Review 107/3 (2002). 
Infants are grossly underrepresented in cuneiform documentation. Because they have no immediate productive value, they are largely absent from administrative texts beyond accounting purposes; because they have very limited agency, they are largely absent from royal inscriptions concerned with conquest and construction; because they have no legal persona in their own right, they are largely absent from legal texts except as the objects of transfers of custody or as the objects of wet-nursing and childrearing agreements-this absence applies to practically every Mesopotamian text category. The important exceptions to this rule are the body of rituals and incantations designed to protect and soothe infants, as well as medical and omen texts concerned with a host of ailments that can afflict infants. ${ }^{85}$ Beyond these circumscribed groups of texts, references to infants in the ancient Mesopotamian textual record are rare and usually isolated in texts that are concerned first and foremost with other issues.

In those rare instances where attitudes to infants are evinced in ancient Mesopotamian texts, they appear to be attitudes of concern and affection. Concern is the prevailing sentiment in most of the texts that are referred to below; affection is often more implicit. By way of quick illustration, I offer an example from the Epic of Gilgameš. In one of the dreams that Gilgameš shares with his mother, he relates that he saw a meteor fall from the sky. A horde of people gathers around it, and Gilgameš says that "they were kissing its feet like a little baby's" (kī šerri lầ unaššaqū šêpī̌šu). ${ }^{86}$ Although we are not dealing with an actual infant, Gilgameš is describing what ancient Mesopotamians might reasonably have expected other ancient Mesopotamians to be doing with infants, namely crowding around them to admire them, all the while cooing and kissing their feet, an act that would—ideally—be rewarded by infant laughter and smiles. It is a happy scene.

85 For incantations, see Farber, Lamaštu, and W. Farber, Schlaf, Kindchen, Schlaf! Mesopotamische Baby-Beschwörungen und-Rituale (Winona Lake: Eisenbrauns, 1989). For medical texts, see R. Labat, Traité akkadien de diagnostics et pronostics médicaux (Leiden: Brill, 1951), N.P. Heeßel, Babylonisch-assyrische Diagnostik (Münster: Ugarit-Verlag, 2000), and J.A. Scurlock and B.R. Andersen, Diagnoses in Assyrian and Babylonian Medicine: Ancient Sources, Translations, and Modern Medical Analyses (Urbana: University of Illinois Press, 2005). For omens, see Šumma Izbu Tablets I-IV in E. Leichty, The Omen Series Šumma Izbu (Locust Valley: J.J. Augustin, 1970).

86 Standard Babylonian Gilgameš Epic I 255 and II 107 in A.R. George, The Babylonian Gilgamesh Epic: Introduction, Critical edition and Cuneiform Texts, Volume I (New York: Oxford University Press, 2003): 552-553, 562-563. 


\subsection{Whence Death?}

In Mesopotamian myth it is the gods who impose death upon humankind, as Utta-napišti, the legendary survivor of the great flood, informs Gilgameš: "life and death did they establish, the day of death they did not reveal" (ištaknū mùta u balàta ša mūti ul uddū ūmī̌su). ${ }^{87}$ The need for death can be traced back to the events that follow the creation of human beings. As is related in Atrahasiss, human beings become so plentiful and troublesome that they keep the god Enlil from sleeping. To control human numbers and noise, various crude methods of population control are pursued, culminating in the mythical flood intended to wipe out humankind. When the flood fails to exterminate the human race but makes painfully obvious the gods' dependence on humanity, further measures are implemented to keep human numbers from growing precipitously without annihilating humankind altogether. The text of Atra-hasis is, unfortunately, very poorly preserved at this point, but among the measures that can be made out are female infertility and the establishment of several classes of women who are socially proscribed from reproducing. ${ }^{88}$

Most important for our purposes is the following measure decreed by the gods in order to limit population growth, which is included along with the others: "let there be the pāšittu-demon among the people; let it snatch the infant from the lap of the one who gave birth to it" (libšima ina nišı̃ pāšittu liṣbat šerra ina birku ălitti). ${ }^{89}$ In other words, the gods decree that there should be an infant-killing demon-whose name can be translated as "annihilator" or "exterminator" — an act that serves as an aetiology for infant loss. The pāšittudemon is not the only demon preoccupied with the slaughter of infants. First and foremost in this regard is the goddess-demon Lamaštu, the daughter of the gods An and Antu, who is cast out of heaven and operates without divine sanction. ${ }^{90}$ Lamaštu is prominent in textual and material evidence from Mesopotamia and beyond from the first half of the second millennium BCE onward, and she is blamed for a panoply of ailments and misfortunes that befall

87 Standard Babylonian Gilgameš Epic x 321-322 in George, The Babylonian Gilgamesh Epic: 698-699.

88 Atra-hasīs II and III in W.G. Lambert and A.R. Millard, Atra-hasīs: The Babylonian Story of the Flood (Winona Lake: Eisenbrauns, 1999).

89 Atra-hasis III vii 3-5 in ibid.: 102-103.

9o For a study of Lamaštu, see F.A.M. Wiggermann, "Lamaštu, Daughter of Anu: A Profile." In Birth in Babylonia and the Bible: Its Mediterranean Setting, by M. Stol (Groningen: Styx, 2000). Wiggermann discusses the possibility that Lamaštu can be identified with Pāšittu on p. 225, but appears to decide against it particularly in F.A.M. Wiggermann, "Pāšittu." In Reallexikon der Assyriologie und Vorderasiatische Archäologie, 10. Band (Berlin: De Gruyter, 2003-2005). 
people in various life stages. Her main business, however, is to trouble and kill infants and small children. As Frans Wiggermann observes in his masterful study, Lamaštu "embodies the worries of parents concerning their offspring."91 Befitting the universality of parents worrying about their offspring, perhaps the most notable aspect of Lamaštu is the broad geographic and chronological range in which texts dealing with her and amulets protecting against her have been found, often in substantial quantities. ${ }^{92}$ The menace that Lamaštu posed to infants was clearly a prominent concern in ancient Mesopotamia.

Descriptions of Lamaštu in incantations guarding against her are very graphic. One of the main themes of these incantations is Lamaštu's murder of infants, as in an Old Babylonian text that says of Lamaštu that "she truly strangles to death the little ones" (șehherūti hunnuqu uhannaq). ${ }^{93}$ To get a more complete sense of the dread with which Lamaštu appears to have been regarded, it is worth reproducing two passages from the first millennium Canonical Lamaštu Series at length:

Canonical Lamaštu Series II 152-162 152. šiptu šurbât mārat Anu mu'ammilat la'ûti

153. rittaša alluhappu kirimmaša mūtu

154. kașat labbat enninat ekkimat nakkipat

155. rahhișat muttabbilat mārat Anu

156. ilappat libba ša harǎšâti

157. išallup šerrī ša tārâti

158. ušennaq unamzaz u ittanaššiq

Incantation: Paramount is the daughter of Anu, who whirls around the babies.

Her hands are a trap, her embrace is death.

Ferocious, raging, wicked, thieving, violent, trampling abductor is the daughter of Anu.

She strikes the women in labour, she tears away infants from the nursing women, she nurses (the infants), sings (to them), and kisses (them) repeatedly.

\footnotetext{
91 Wiggermann, "Lamaštu": 248.

92 For amulets see ibid.: 219-224, and E. Götting, "Exportschlager Dämon? Zur Verbreitung Altorientalischer Lamaštu-Amulette." In Exportschlager: Kultureller Austausch, wirtschaftliche Beziehungen und transnationale Entwicklungen in der antiken Welt, ed. J. Göbel and T. Zech (Berlin: Herbert Utz, 2011); for texts see Farber, Lamaštu: 7-66.

$\mathrm{OB}_{1}$ 10-11a in ibid.: 148-149.
} 
159. rabû kakkūša namšišū širānūšša

16o. qadištu mārat Anu ša ilī ahh̆̌̌ša

161. qaqqassa qaqqad nēšsi šinnat imēri šinnassa

162. šaptāša ziqziqqumma utabbakā mūta

\section{Canonical Lamaštu Series I 117-131}

117. mārat Anu ūmišamma erâti imannu

118. arki ālidāti ittanallak

119. arhǐšsina imannu ūmō̌sina ina igāri ușsar

120. ana ālidāti nadât šipta

121. bilāni mārīkina lušēniq

122. ana pî mārātīkina tulâ luštakkan

123. našât ina qātiša umma kușṣa hurbāša mamma katimta 124. nablì muhammițūti mali zumurša 125. azzūzâ izarri imta

126. ana sursuru izarri imta

127. imat șerri imassa imat zuqaqīpi imassa

128. ețlūti šuggušu ušaggaš 129. ardāti hubbulu uhabbal 130. șehrūti nuppușu unappaș 131. batūlāti išaqqâ mê pušqi
Mighty are her weapons, her muscles are agile.

The daughter of Anu is the qadištu of the gods, her siblings.

Her head is the head of a lion, her teeth are the teeth of a donkey. Her lips are a tempest: they pour out death. ${ }^{94}$

The daughter of Anu numbers the pregnant women daily, follows continually behind those about to give birth.

She numbers their months, she keeps watch over their days from the wall. She casts a spell upon those about to give birth:

"Bring me your sons that I may suckle (them)!

Let me place a breast in your daughters' mouths!"

She carries in her hand fever, cold, chills, frost, and a concealed ailment. Her body is full of scorching flames. In every region she scatters poison. At great speed she scatters poison. Her venom is the poison of the snake, her venom is the poison of the scorpion.

She truly murders young men, she truly ravages young women, she truly smites the little ones, she makes girls drink the water of distress. ${ }^{95}$

\footnotetext{
94 Canonical Lamaštu Series II 152-162 in Farber, Lamaštu: 178-179.

95 Canonical Lamaštu Series I 117-131 in ibid.: 154-157.
} 
These passages articulate the negative qualities and behaviours that were attributed to Lamaštu. She is an abductor and a murderer, expert in killing infants, lurking at the wall and ever vigilant in her search for new victims. Nobody is safe from Lamaštu, who can strike at any moment: "without being Death, she has cut his throat, without being a gallu-demon, she has wrung his neck. She has strangled the little one in the wetnurse's lap" (balu müti ittakis kišāssu balu gallê napištašu uttīr ina sūni mušēniqti ihtanaq șuhāara). ${ }^{96}$ Lamaštu is cruel, unpredictable, and uncontrollable. She is the personification of infant loss, and her characterization as evil conveys the anxiety and pain that infant loss generated among ancient Mesopotamians. ${ }^{97}$

Infant loss comes not only in the form of Lamaštu and the Pāšittu-demon, though Lamaštu is certainly its most visible manifestation in the surviving textual record. Following the creation of humankind in the Sumerian creation myth Enki and Ninmah, the mother-goddess Ninmah creates a series of seven humans with various abnormalities. Enki nevertheless finds a place for these people within human society, before himself producing a human suffering from abnormalities. This human is called Ummul, ${ }^{98}$ and Enki challenges Ninmah to find it a place in human society. Again, the relevant passage is worth reproducing at length:

\section{Enki and Ninmah II 54-70}

54. $\mathrm{gi}_{4}$-bi $\mathrm{u}_{4}$-mu-ul a-za-ad-bi gig-ga ki-NAM-esir 2 -bi gig-ga

55. igi-bi gig-ga gu ${ }_{2}$-bi gig-ga zi ušs ${ }_{2}^{-}$ ušs $\check{s}_{2}$ ti sur-sur

56. mur gig-ga ša ${ }_{3}$ gig-ga lipiš gig-ga
This was Ummul: its head was afflicted, its brow was afflicted, its eye was afflicted, its neck was afflicted, its throat was blocked, its ribs were twisted, its lungs were afflicted, its heart was afflicted, its innards were afflicted.

96 Canonical Lamaštu Series I 155-157 in ibid.: 156-157.

97 For parallels to Lamaštu and Pāšittu from the Greek world see S.I. Johnston, "Defining the Dreadful: Remarks on the Greek Child-Killing Demon." In Ancient Magic and Ritual Power, ed. M. Meyer and P. Mirecki (Leiden: Brill, 1995), though these parallels are likely derived from Mesopotamian traditions.

98 Ummul is written $\mathrm{u}_{4}$-mu-ul, where $\mathrm{u}_{4}$-mu designates "my day". The "ul" element ordinarily represents something like "distant", for a meaning along the lines of "my day is distant". It is, however, also possible to read "ul" as the negative, so that it is conceivable-and probably preferable on contextual grounds - to read Ummul as "my day is not", or "I will not have my day". 
57. šu-ne ${ }_{2}$ a-za-ad la ${ }_{2}-\mathrm{la}_{2}$ ka-bi-še ${ }_{3}$ ninda nu-ğar

58. murgu lum-lum gu-du ze ${ }_{2}$-re zag-še sur

59. ĝir ${ }_{3}$ sur-sur a-gar ${ }_{3}$ nu-gub

$\mathrm{am}_{3}$-ma-ni-in-dim ${ }_{2}$

6o. ${ }^{\mathrm{d} e n-k i-k e}{ }_{4}{ }^{\mathrm{d}}$ nin-mah-ra gu $\mathrm{u}_{3}$ mu-na-de ${ }_{2}$-e

61. $\operatorname{lu}_{2}$-šu-dim 2 -ma-zu nam i-ni-intar ninda mi-ni-g[ $\left[\mathrm{u}_{7}\right]$

62. za-e lu lu$_{2}$-šu-dima 2 -ma-mu-uš nam-bi tar-ra-ab ninda h $\mathrm{h}\left[\mathrm{e}_{2}\right]-\mathrm{gu}_{7}$

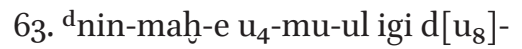
a-ni-ta x-bi-ša ${ }_{3}$ ba-e-gi ${ }_{4}$

64. $\mathrm{u}_{4}$-mu-ul mu-na-te en ${ }_{3}$ mu-natar-tar-re SAG-bi nu-ba-e 65. ninda gu ${ }_{7}$-a-ni-še ${ }_{3}$ mu-na-abšum $_{2}$ šu nu-mu-na-da-gid ${ }_{2}$ 66. šu-ni mi-ni-in-ba nu-mu-da-anzi-zi

67. ğ $^{\mathrm{s} g u r} \mathrm{gu}_{8}-\mathrm{u}_{6}-\mathrm{ša}_{3}$ nu-mu-na-na 2 nu-mu-da-an-na ${ }_{2}-$ na $_{2}$

68. gub nu-mu-da tuš nu-mu-da na $_{2}$ nu-mu-da x x nu-mu-da ni $\hat{g}_{2}$ nu-mu-da-da

69. ${ }^{\mathrm{d}}$ nin-mah-e den-ki-ra inim-ma mu-n[a-x-(x)]-x 7o. $\operatorname{lu}_{2}$-šu-dim ${ }_{2}$-ma-zu lu lutil $_{3}$-la innu $\mathrm{lu}_{2}-\mathrm{u}\left[\check{s}_{2} \mathrm{i}\right] \mathrm{n}$-nu il ${ }_{2}$-bi nu-mu-da
With its hand and droopy head it could not put food in its mouth. Its spine was twisted, its buttocks were torn, its shoulder slouched, Its feet were crooked, it could not stand on the ground: (thus) he had fashioned it.

Enki said to Ninmah,

"I have decreed destinies for the creatures you fashioned, I have given them sustenance.

(Now) you decree the destiny for the creature that I fashioned and give it sustenance."

Ninmah looked upon Ummul and turned to it.

She approached Ummul and asked it questions, but it could not speak. She brought it bread to eat, but it could not stretch out its hand. She offered it her hand, but it could not rise.

She set up a bed? for it, but it could not lie down in it.

It could not stand, it could not sit, it could not lie down, it could not...: it could not do anything. Ninmah [answered] Enki,

"The human that you fashioned is neither alive nor dead! I cannot bear it!" 99

99 Enki and Ninmah II 54-70 in W.G. Lambert, Babylonian Creation Myths (Winona Lake: Eisenbrauns, 2013): 338-341. 
Ummul has been variously understood to represent an old man, ${ }^{100}$ a baby, ${ }^{101}$ a premature infant, ${ }^{102}$ and a foetus about to be born. ${ }^{103}$ In the present reading, Ummul is not any of these. The section of Enki and Ninmah in which Ummul appears represents an aetiology of disability, as has been pointed out by Aage Westenholz. ${ }^{104}$ Ninmah acts as the midwife for the birth of Ummul, and she is introduced to Ummul as soon as it is born. While the abilities of newborns are very limited, it is difficult to align the description of Ummul, and in particular the description of its physical impairments, with newborns in general. Contextually, then, it makes most sense to interpret Ummul as a newborn infant suffering from profound and incurable disabilities. ${ }^{105}$ Accordingly, Ummul functions as an aetiology for the birth of infants whose severe disabilities leave them with little to no chance of survival in ancient societies. Infants matching this criterion are born in small numbers in every time and place, provoking the question of why such helpless beings are born at all. Although Enki and Ninmah does not provide a clear answer to that question, ${ }^{106}$ it does fit the existence of profoundly disabled infants - many of whom go on to perish not long after birth-into a broader mythological framework.

The second half of the Ummul episode in Enki and Ninmah is very poorly preserved, and any interpretation of the text must perforce remain speculative. It is nevertheless unmistakable that the creation of Ummul is a source of great distress to the mother-goddess Ninmah, and Enki has to coax her to let go of pitiful Ummul: "remove from your bosom Ummul, who is held at the breast!"

100 Th.Jacobsen et al., Before Philosophy:The Intellectual Adventure of Ancient Man (Baltimore: Penguin, 1949): 177 .

101 A. Draffkorn Kilmer, "Speculations on Umul, the First Baby." In Kramer Anniversary Volume: Sumerological Studies in Honour of Samuel Noah Kramer, ed. B.L. Eichler (Kevelaer: Butzon \& Bercker, 1976). Kilmer even goes so far as to identify Ummul with the Mesopotamian flood hero.

102 Th. Jacobsen, The Harps that Once... Sumerian Poetry in Translation (New Haven: Yale University Press, 1987): 152-153.

103 Stol, Birth in Babylonia: 109-110.

104 A. Westenholz, "Enki and Ninmah: An Interpretation." In A Woman of Valor: Jerusalem Ancient Near Eastern Studies in Honor of Joan Goodnick Westenholz, ed. W. Horowitz, U. Gabbay, and F. Vukosavović (Madrid: Consejo Superior de Investigaciones Científicas, 2010).

105 Knowledge of such infants in ancient Mesopotamia is documented extensively in Tablets I-IV of Šumma Izbu, for which refer to Leichty, The Omen Series Šumma Izbu.

1o6 Samuel Noah Kramer and John Maier suggest the reason is as trivial as compelling Ninmah to recognize Enki's superiority in a drunken contest: S.N. Kramer and J. Maier, Myths of Enki, the Crafty God (New York: Oxford University Press, 1989): 14, 31. 
( $\mathrm{u}_{4}$-mu-ul gaba-zu dab ${ }_{5}$-ba ur ${ }_{2}$-zu-ta šu gala ${ }_{2}$-ab-ta).107 In a difficult passage at the very end of the section, Enki consoles Ninmah and declares, "Ummul, may he make my house!" ( $\mathrm{u}_{4}$-mu-ul du $\mathrm{d}_{3}$-a $[\mathrm{x}(\mathrm{x})] \mathrm{e}_{2}$-mu he $\mathrm{e}_{2}$-ak-[e]). ${ }^{108}$ While it appears that Ummul is being honoured in some way in this line, it is not certain what precisely the implications of Enki's utterance are. It is, however, possible to link Enki's utterance to the practice of intramural infant burial. In this view, intramural inhumation of infants is regarded as tantamount to the provision of a figurative foundation for a house, and perhaps this is what is being alluded to. Although this contention cannot be proven at present, it does align with the archaeological and textual data.

In Mesopotamian mythology, infant loss has a clear origin in the divine need to exercise some level of control over human numbers and in the murderous activities of the goddess-demon Lamaštu. The birth of disabled infants with little chance of survival can in turn be traced to the design of the god Enki, even if it remains unclear why such creatures were fashioned in the first place. Inscrutability, however, is typical of the gods: "who can learn the plan of the gods in the heavens?" (ayyu țēm ilì qereb šamê ilammad). ${ }^{109}$

\subsection{The Evils of Infant Loss}

When infants died in ancient Mesopotamia, as inevitably many did, the relevant texts indicate that this was regarded as a lamentable tragedy. Infant loss is invariably depicted as an evil, and it seems clear that the response to infant loss was one of manifest and pervasive grief. On a conceptual level, infants were already regarded as distinct beings before they were born. Numerous incantations dealing with childbirth concern themselves with the infant directly, as in the following line from a Middle-Assyrian text, "bring forth that sealed-up one, a creation of the gods, a creation of man. Let it come out and let it see the light!" (šêli kakka šâti bunūt ilāni bunūt a'îli luṣāma lèmur nūra);110 the unborn foetus is likewise recognized as a distinct entity in a passage from a medical text that describes it as "a separate being, a creation of humankind" (eșemtu ahìtum binūt amèlūti). ${ }^{111}$ Given the conceptual recognition of even unborn

107 Enki and Ninmah II 101 in Lambert, Babylonian Creation Myths: 342.

108 Enki and Ninmah II 110 in ibid.: 342.

109 Ludlul bēl nēmeqi II 36 in A. Annus and A. Lenzi, Ludlul bēl nēmeqi: The Standard Babylonian Poem of the Righteous Sufferer (Helsinki: The Neo-Assyrian Text Corpus Project, 2010): 20.

110 Lines 48-49 in W.G. Lambert, "A Middle Assyrian Medical Text." Iraq 31 (1969): 31.

111248 II 54-56 in F. Köcher, Die babylonisch-assyrische Medizin in Texten und Untersuchungen (Berlin: De Gruyter, 1963). 
infants as distinct individuals ${ }^{112}$ rather than as indistinct entities, the mourning provoked by their passing is all the more understandable.

After Lamaštu murders a little boy in one Lamaštu text, "she seizes the chair of mourning in her hand, she gathers the dust of mourning in her hand" (kussu kihulê ina qātišsa ișbat eper kihulê ina qātīša išbušs). ${ }^{113}$ Infant loss is thus associated directly with grief. Likewise, Lamaštu's activities are said to provoke mourning wherever she strikes: "[... in the] house she has set wailing, [...] for humankind she has left behind mourning" ([...] bitti iltakan bikita [...] ana amèlūtì damāma ìzib). ${ }^{114}$ Lamaštu's actions are yet again linked with grief when she is asked rhetorically: "have you grown accustomed, oh daughter of Anu, to the food of wailing and weeping? You keep drinking the putrid blood of humankind!" (taltamdī mārat Anu akal dimmati u bikīti taltanattî dāmī našpūti ša amēelütī). ${ }^{115}$ The tone of these passages leaves no room for ambiguity. According to the Lamaštu literature, infant loss is an evil that is greeted with great lamentation.

The human dimension of this grief is illustrated by a letter from the Old Babylonian kingdom of Mari. While Zimri-limm, the king of Mari, is away, one official in his service writes to another that the king's daughter has died shortly after her birth. The letter expresses great concern that the king be notified of this unfortunate development before he returns to Mari, lest "the king hear of the death of that little one when he enters (Mari) and become profoundly distressed" (ina erēbišu mūt șeherti šâti šarru išemmēma ișabbat itaššuššam). ${ }^{116}$ Apparently, Zimri-lim's officials were worried that he would be overcome with anguish at news of his daughter's death. To the extent that Zimri-lim can be taken to represent an average ancient Mesopotamian, the natural response to infant loss is once again one of grief.

This attitude to infant loss is echoed in other Mesopotamian texts. In the Epic of Erra and Išum, Erra's destructive impulses are directed against all elements of the civilized order. Several times, Erra targets infants. Whenever infant-killing is introduced, it is generally as the climax in a series of morally

112 Though their identity was still in the process of formation and they were not yet effectively individuated. There was, after all, no way of knowing an infant's sex or physical characteristics until birth, which inhibits the naming process and the shaping of a coherent social identity.

113 Canonical Lamaštu Series I 138-139 in Farber, Lamaštu: 156-157.

114 Canonical Lamaštu Series I 168-169 in ibid.: 156-159.

115 Canonical Lamaštu Series I 189-19o in ibid.: 158-159.

116 ARM 26/1 222 [A.3724] 21-25 in J.-M. Durand, Archives épistolaires de Mari. Archives Royales de Mari XXVI (Paris: Recherches sur les Civilisations, 1988): 451. 
depraved acts. This is apparent in the following passage, in which Erra incites the governor of Babylon to issue morally odious orders to one of his military commanders:

\section{Erra IV 25-30}

\section{5. ālik pān ummāni ušahhaza lemutta}

26. ana āli šâšu ša ašapparukka atta amèlu

27. ila là tapallah lā taddar amēla

28. șehru u rabâ ištêniš šümitma

29. èniq šizbi šerra lā tezzib ayyumma

30. nakma būšê Bābili tašallal atta
He instructed the commander of the army to do evil: "You, man! In that city whither I am sending you, revere no god! Fear no man! Put young and old to death as one! Spare not a single suckling child, not an infant! You will plunder the accumulated wealth of Babylon!"117

In this sequence, killing infants is the epitome of unbridled violence. In another iteration of his socially destructive rage, Erra boasts that he has killed infants, so that "I deprive the nursing woman of the clamour of infant and baby" (ikkil šerri u la î tārìtu uzamma). ${ }^{118}$ In still another such passage, Erra's bloodlust is not yet sated and he tells Išum to let him engage in further destruction, which includes a particularly nasty way of killing off infants: "let me dry up the breast, so that the infant will not live!" (tulâ lušăbilma ul iballuț šerru). ${ }^{119}$ In the Epic of Erra and Išum, as in the Lamaštu literature, infant loss is a destructive evil and bringing it about is the apex of unrestrained cruelty.

Remarkably - and despite the fact that they share some responsibility for its existence-even the gods do not seem to be well disposed to infant loss. In Ištar's Descent to the Netherworld, the netherworld goddess Ereškigal is surprised that Ištar has come down to her realm. Disturbed, Ereškigal expresses the wish to be left alone to proceed with her usual activities, which include crying over dead infants, and she instructs her gatekeeper to "let me weep for the baby infant, who was sent away before his time!" (ana šerri lakê lubki ša ina lā ümišs țardu)..$^{120}$ One passage from the Canonical Lamaštu Series appears to

117 Erra IV 25-29, in Cagni, L'Epopea di Erra: 106-107.

118 Erra IIIa 17, in ibid.: 92-93.

119 Erra IV 121, in ibid.: 116-117.

120 Ištar's Descent 36 in P. Lapinkivi, The Neo-Assyrian Myth of Ištar's Descent and Resurrection (Helsinki: The Neo-Assyrian Text Corpus Project, 2010): 17. Jean Bottéro and Samuel Noah Kramer understand this line to represent one of Ereškigal's thoughts about Ištar's 
attribute Lamaštu's expulsion from heaven by her parents to her reprehensible slaughter of infants. Lamaštu's begetters even deny her the human worship that should be her due as a divinity: "Anu her father and Antu her mother cast her down from heaven because of her unseemly deeds; they did not establish her shrine on earth" (Anu abuša Antu ummašāma ina epšèttǐša lā banâti ištu šamê ušeridūniššimma ul iddû parakkaša ina erșeti). ${ }^{121}$ Elsewhere in the Canonical Lamaštu Series, Lamaštu is spotted indulging in a bout of infantkilling by the god Marduk/Asalluhi, who promptly informs on her to the god Ea: "Asalluhi saw her and spoke to his father Ea: 'My father, I saw the daughter of Anu, she was collecting babies!' Ea answered his son Marduk: 'Go, my son Marduk!'” (īmuršìma Asalluhi ana Ea abī̌su amāta izakkar abī āmur mārat Anu ša ušabbaša la'ûti Ea māršu Marduk ippal alik mārī Marduk). ${ }^{122}$ Ea grasps the severity of the problem and responds promptly, sending Marduk back to Lamaštu and giving him instruction on how to stop her with his help and that of the gods Nabû and Šamaš. Four great gods thus combine their powers to stop Lamaštu's cruel exploits. One may wonder that so many gods who are so opposed to Lamaštu are somehow unable to put a permanent end to her activities, but the paramount sentiment is resounding: in ancient Mesopotamian texts, infant loss is an abomination to humans and gods alike, a destructive force that brings with it much mourning.

\subsection{Resisting Infant Loss}

Infant loss was an evil that could strike without warning, but this did not mean that ancient Mesopotamians waited passively for death to deprive them of their offspring. A great number of texts give a sense of the scale of the efforts that ancient Mesopotamians channelled into the warding off of infant loss. Practically the entire corpus of Lamaštu texts, for instance, owes its existence to its apotropaic function. Lamaštu texts exist to keep Lamaštu at bay, which they accomplish by means of the various incantations and rituals they record and often also by their incorporation into amulets. The incorporation of Lamaštu texts in amulets is recorded in the very beginning of the Canonical Lamaštu Series: "you inscribe [the incantation] on a cylinder seal

possible motivations for descending to the netherworld, so that it is Ištar who wants to weep for the babies who died before their time. Either way, weeping for deceased infants remains one of the occupations associated with the netherworld. See J. Bottéro and S.N. Kramer, Lorsque les dieux faisaient l'homme. Mythologie mésopotamienne (Paris: Gallimard, 1989): 320.

121 Canonical Lamaštu Series I 111-113 in Farber, Lamaštu: 154-155.

122 Canonical Lamaštu Series II 167-170 in ibid.: 178-179. 
of clay (and) place it around the infant's neck" (ina muhhi kunuk țidi tašatțar šerru ina kišădišu tašakkan). ${ }^{123}$ In some Lamaštu incantations, the daughter of Anu is commanded to release her victims, to which end various higher powers are invoked. In the following example, that higher power is the legendary sage Adapa, who turns his attention to driving out Lamaštu:

\section{Canonical Lamaštu Series II 22-26}

22. eppēšu Adapa apkal Eridu

23. dāgilki ina Eridu inaț̣alki kâši

24. unakkar imatki inassah qātīki

25. ina zumur šerri mār ilı̌šu annî

26. putrī atlakī $\mathrm{TU}_{6} \cdot \mathrm{EN}$
Crafty Adapa, sage of Eridu, he can see you, in Eridu he scrutinizes you: yes, you!

He will neutralize your venom, he will tear away your hands from the body of this infant who is in the care of his god.

Let go! Get thee gone! (Magic Formula) $)^{124}$

Wherever Lamaštu is deemed responsible for the ailments from which infants suffer, the widespread body of Lamaštu texts provides instruction to ancient Mesopotamians in how to combat her effectively.

When ailments were amenable to more mundane medical intervention they were treated accordingly. ${ }^{125}$ In their compendious study of Mesopotamian diagnostic medicine, JoAnn Scurlock and Burton Andersen find that considerable attention is paid to the medical problems of infants and small childrenindeed, one tablet of the diagnostic and prognostic series Sakikkû is allocated specifically to infant diseases. Communicable diseases, seizures, and other problems are all diagnosed and assessments are made as to the likely outcome for infants suffering from the symptoms described. ${ }^{126}$ Some diagnoses are in harmony with modern paediatric medicine, particularly with regard to teething, which is identified as a cause of mild fever and drooling; symptoms are

123 Canonical Lamaštu Series I 1ob in ibid.: 144-145.

124 Canonical Lamaštu Series II 22-26 in ibid.: 164-165.

125 For a general overview of the maladies reported to be afflicting children in cuneiform texts—and not specifically infants—along with their cultural context, see K. Volk, "Kinderkrankheiten nach der Darstellung babylonisch-assyrischer Keilschrifttexte." Orientalia Nova Series 68.1 (1999).

126 Scurlock and Andersen, Diagnoses in Assyrian and Babylonian Medicine: 316-317, Chapter 17 . 
expected to persist for two to three weeks. ${ }^{127}$ In other cases, Mesopotamian medics turn to straightforward solutions, as in the following example: "if $a \check{s} \hat{u}$ and samānu afflict an infant, you move him away to a new breast and continually recite an incantation over him and he will recover" (šumma šerru ašû u samāni iṣbassu ana tulâ ešša tunakkaršūma u šipta tattanaddinšumma iballut). ${ }^{128}$ In other words, the medical problem is thought to be transmitted through drinking a woman's milk, and supplying the infant with a different source of milk ought to put an end to the malady. Scurlock and Andersen conclude that the ancient Mesopotamian medical professional "appears to have been as concerned with the care of infants and children as he was with adults. He understood common, benign childhood problems such as teething and colic, as well as serious and life-threatening infections. Congenital anomalies were also described." 129

Occasionally, evidence of the practical application of some of the knowledge preserved in Mesopotamian medical texts survives. With regard to infants, this is true for some of the correspondence of the Assyrian king Esarhaddon (681-669 BCE). Several letters between Esarhaddon and his exorcists and physicians document the king's close interest in the physical wellbeing of the children of his household, the fact that they nevertheless suffered from health problems, and the treatments that they were subjected to in order to restore them to health. In a report about one unspecified baby, the chief physician Urad-Nanaya informs the king that "the baby is doing very well. I tied a bandage over this abscess that is behind his ear, it rested loosely against its tip" (šulmu adanniš ana lakû sikru hanniu ša kutal uznišu tal'îtu ina muhhi urtakis ina appišu irtumu). ${ }^{130}$ Despite the presence of a great deal of pus on the bandage, Urad-Nanaya promises that the infant will be better in seven or eight days. The royal exorcist Nabû-nașir diagnoses an infant as suffering from complications related to teething: "the fever with which [the infant's] head, hands, and feet burned is because of his teeth: his teeth were coming out." (șarāhu ša rēssu idāšs šêpāšsu ișșarhūni issi pān šinnēšsu šinnūšu ana ușê). ${ }^{131}$ By the time the letter was written, the infant had recovered. Aššur-mukin-palē'a-one of Esarhaddon's sons-appears to have suffered from persistent health problems

\footnotetext{
127 Ibid.: 411-412.

12817.144 in ibid.: 410.

129 Ibid.: 417.

130 SAA X 319 8-14 in S. Parpola, Letters from Assyrian and Babylonian Scholars (Helsinki: Helsinki University Press, 1993): 257-258.

131 SAA X 302 11-r.3 in ibid.: 241.
} 
and is the subject of at least four letters reporting to the king on his wellbeing. ${ }^{132}$ The tone of these letters is typically very reassuring: "Aššur-mukīn-palē'a is doing very, very well! My lord can be glad indeed!" (šulmu adanniš adanniš ana Aššur-mukin-palè’a libbu ša šarri bēlīa lū țābšu). ${ }^{133}$ In a separate letter, UradNanaya extends such reassurances to the king on behalf of all of the king's offspring, writing, “Aššur-mukīn-palēa is doing very well. The king mustn't fear this fever which seized him two or three times: his illness is fine and normal, he is well. The baby, the crown prince, and the children of the king, my lord, they are all well" (šulmu adanniš ana Aššur-mukīn-palē’a hunțtu anniu ša 2-šu 3-šu iṣbatūšuni šarru lā ipallah sakikkūšu šulmu tariș šumu šù šulmu ana lakû ana mār šarri ana mārê šarri bēlìa gabbu ina muhhi bulți). ${ }^{134}$

Medical treatment of infants included a considerable amount of what might be regarded as preventative medicine. To keep infants from falling ill, numerous measures were taken to ward off the perceived causes of disease, namely assorted demons and other malevolent forces. With reference to one infant, the exorcist Nabû-nașir writes to Esarhaddon that "until Aššur, Bēl, and Nabû, your gods, counted him among the adults, we did not leave a day or a month without rituals and rites" (adu Aššur Bēl u Nabû ilānīka issi nišê imnūšūni ūmu u urhu lā nibțili ša lā dullu u nēpēši $)^{135}$ Another very poorly preserved letter documents the placement of amulets on small children in order to cure epileptic seizures, an operation that the letter reports was successful. ${ }^{136}$

Other magical-medical treatments seeking to protect infants abound. Walter Farber has collected a host of incantations and rituals that aim to ward off various evil forces that might be conspiring to harm infants or cause uncontrollable crying. ${ }^{137}$ Some of these rituals involve very particular ingredients, including the hairs of various animals, snakeskin, scorpion tail, and other exotic substances, which indicates the length to which people were prepared to go to keep their infants out of death's grasp. One Late Babylonian Lamaštu ritual from Uruk is directed against repeated miscarriage and/or stillbirth.

132 SAA X 296, 298, 299, and 300 in ibid.: 238-241. SAA X 301, 305, and 306 also appear to deal with inquiries concerning the health of infants, while the poorly preserved letter SAA $\mathrm{X}$ 293 evinces great concern on the part of the king over a royal childbirth.

133 SAA X 299 6-9 in ibid.: 240.

134 SAA X 320 7-15 in ibid.: 258.

135 SAA X 298 r.5-r.9 in ibid.: 239-240.

136 SAA X 309 in ibid.: 248-249.

137 Farber, Schlaf, Kindchen, Schlaf! For a necessary rethinking of the character of these texts, see K. van der Toorn, "Magic at the Cradle: A Reassessment." In Mesopotamian Magic: Textual, Historical, and Interpretative Perspectives, ed. T. Abusch and K. van der Toorn (Groningen: Styx, 1999): 139-147. 
It involves the fashioning of a Lamaštu figurine and numerous ritual acts including a request for absolution from sins and a threefold repetition of the following speech act: "I was pregnant, but I did not carry to term; I gave birth, but I did not create life" (êri ul ušallim ülid ul abni). ${ }^{138}$ While it is easy to dismiss the medical value of such treatments — reliant as they are on ritual — there was genuine faith in their efficacy. Yağmur Heffron notes that "just as anxious parents today may be tempted to rush colicky babies to the doctor, Mesopotamian mothers and fathers would have sought answers from the medical specialists available to them, namely, incantation priests."139 Ancient Mesopotamians were prepared to go to great lengths in order to keep their infants alive and healthy.

\subsection{Grappling with Infant Loss}

In ancient Mesopotamia, infant loss had its own place in the broader mythological scheme, was regarded as an evil and a source of grief, and was resisted with vigour. Beyond the availability of local social support networks, consolation of the bereaved extended into the development of conceptualizations of the netherworld in which infants - and particularly the stillborn-enjoyed a privileged position. Most notable in this regard is the Sumerian literary text Gilgameš, Enkidu, and the Netherworld. ${ }^{140}$ In this narrative, Enkidu descends to the netherworld, the home of all who die, and is trapped. The sun god Utu extracts Enkidu from the netherworld, and Enkidu then proceeds to answer Gilgamešs questions about the fate of various categories of dead people. Generally, people in the netherworld are depicted living wretched existences, such that Gilgameš has to sit down and weep while Enkidu describes the Netherworld to him. There are very few exceptions to this dreary prognosis, but the one that is most striking pertains to stillborn infants:

Gilgameš, Enkidu, and the Netherworld 303-304

niĝin-ĝar tur-tur-ĝ̣u $\mathrm{u}_{10}$ ní-ba nu-zu igi bí-du -àm igi bí-du $_{8}$-àm a-na-gin an-ak ĝ̀išbanšur kug-sig ${ }_{17}$ kug-babbar làl ì-nun-ta e-ne im-di-e-ne ${ }^{141}$

\footnotetext{
138 SpTU 10a in Farber, Lamaštu: 308-309.

139 Y. Heffron, "Revisiting 'Noise' (rigmu) in Atra-hasiss in Light of Baby Incantations." JNES 73/1 (2014): 92-93.

140 Also refer to fn. 42 for burial practices for stillborn infants that have a connotation of healing.

141 Gilgameš, Enkidu, and the Netherworld 303-304 in A. Gadotti, Gilgamesh, Enkidu, and the Netherworld, and the Sumerian Gilgamesh Cycle (Berlin: De Gruyter, 2014): 16o, 168.
} 
"Did you see my stillborn little ones who did not know themselves?" "I saw them". "How are they doing?" "They enjoy syrup and ghee at tables of silver and gold". ${ }^{142}$

Gilgameš, Enkidu, and the Netherworld has some small lacunae and in any case does not cover every conceivable class of dead person, but it is nevertheless perfectly clear that the fate of the stillborn is the envy of that of the other netherworld denizens described in the text. ${ }^{143}$

In a society that is not invested in the wellbeing of its infants or that is emotionally unattached to them, there is little reason for the development of a tradition concerning the prospects of deceased infants-and stillborn infants in particular-like that which is articulated in Gilgameš, Enkidu, and the Netherworld. By imagining a happier fate for infants in an afterlife than that which they were able to enjoy in actuality, some bereaved parents and caregivers can find a measure of solace and consolation for their loss. It is precisely this purpose that the image of stillborn children enjoying themselves in the netherworld is designed to serve. ${ }^{144}$ It is worth emphasizing that the approach to the place of dead infants in the afterlife illustrated in Gilgameš, Enkidu, and the Netherworld is far from universal; one need only look to the concepts of

142 In ibid.: 120, 300, Alhena Gadotti argues that this passage refers specifically to Gilgameš's $\left(-\hat{g}_{10}=\right.$ "my") stillborn infants rather than to stillborn infants in general. This seems to me to be an intrusive interpretation given that the text deals with general categories of deceased persons; it makes little sense to personalize one category of people in a list that is otherwise wholly impersonal, particularly because there is no reason to associate Gilgameš specifically with stillbirth. The - $\hat{g} \mathrm{u}_{10}$ suffix is best understood either as a claim of personal concern and responsibility for the stillborn or as an additional way of expressing the diminutive.

143 This has recently been remarked upon by Jerrold Cooper in J.S. Cooper, "Wind and Smoke: Giving up the Ghost of Enkidu, Comprehending Enkidu's Ghosts." In Rethinking Ghosts in World Religions, ed. M. Poo, (Leiden: Brill, 2009): 25, 30. Bendt Alster has argued that the person described as lying on the bed of the gods is better off than the stillborn, but it is not clear what lying on the bed of the gods means, whereas there is no ambiguity about the positive quality of the fate of the stillborn and its appropriateness for infants. Alster's interpretation of the identity of the man lying on the bed of the gods as one who died early in life is also not secure. See B. Alster, Wisdom of Ancient Sumer (Bethesda: CDL Press, 2005): 340 .

144 The consolatory function of this passage from Gilgameš, Enkidu, and the Netherworld has already been noted in passing by Rivkah Harris, though she appears to understand it as referring to Gilgameš's own stillborn infants. See R. Harris, Gender and Aging in Mesopotamia: The Gilgamesh Epic and other Ancient Literature (Norman: The University of Oklahoma Press, 2000): 16. See also fn. 142 above. 
infant limbo and infant damnation promoted by certain historical church authorities to see that alternate developments that are much less generous to infants and bereaved parents and caregivers are possible. ${ }^{145}$

Also relevant to stillborn infants is the term "Kūbu", which has been understood to signify the deified stillborn child. ${ }^{146}$ This identification rests largely on the equation of the Kübu with a human being that cannot drink its mother's milk - presumably because it is dead: "as a corpse cannot cross the gate of life, as a Kübu cannot drink its mother's milk" (kìma pagru lā ètiqu bāb balāti kìma dKù-bu lā èniqu šizib ummišsu), "as a corpse has no ... a Kūbu cannot drink its mother's milk" (kima pagru lā išsu [...] ${ }^{\mathrm{d} K u ̀-b u ~ l a ̄ ~ i ̀ n i q u ~ s ̌ i z i b ~ u m m i s ̌ u) . ~}{ }^{147}$ The identification of the Kūbu with the deified stillborn is imperfect; Marten Stol has challenged this position, arguing that the Kübu represents not a stillborn child but a foetus at an advanced stage of development. ${ }^{148}$ It is conceivable that the Kūbu can signify both in different contexts. If becoming a Kūbu does represent a possible fate for stillborn infants, then the implications are ambiguous. On the one hand, the Kübu is worshipped in shrines and appears as a theophoric element in numerous names from the Ur III period through to the Neo-Assyrian period. ${ }^{149}$ On the other hand, the Kübu is associated with various medical problems. ${ }^{150}$ It might be that the conceptualization of the Kūbu was variable, so that it is not necessary to imagine that scribes separated by broad expanses of time and space had precisely the same thing in mind when using the term Kübu. In any case, there is nothing overtly negative about being a Kūbu even if the Kūbu did have a hand in certain ailments. By contrast, being worshipped in a shrine and incorporated in personal names is an indication of the importance and positive role of the Kübu.

145 See for instance M.E. Stortz, “'Where or When Was Your Servant Innocent?' Augustine on Childhood." In The Child in Christian Thought, ed. M.J. Bunge (Grand Rapids: Eerdmans, 2001).

146 For examples of this position, seeW.H.Ph. Römer, "Einige Bemerkungen zum dämonischen Gotte dKūbu(m)." In Symbolae Biblicae et Mesopotamicae: Francisco Mario Theodoro de Liagre Dedicatae, ed. M.A. Beek et al (Leiden: Brill, 1973), and W.G. Lambert, "Kūbu." In Reallexikon der Assyriologie und vorderasiatische Archäologie, Band VI: KlagesangLibanon, ed. E. Ebeling et al (Berlin: De Gruyter, 1980-1983).

147 Römer, "Einige Bemerkungen”: 310-311.

148 Stol, Birth in Babylonia: 29-32.

149 Römer, "Einige Bemerkungen": 316-318. For the Neo-Assyrian period, see the names BurKūbi, Kūbu-ēreš, and Kūbu-rundu in The Prosopography of the Neo-Assyrian Empire: 354, 632.

150 Scurlock and Andersen, Diagnoses in Assyrian and Babylonian Medicine: 512-514. 


\subsection{Infanticide and Infant Exposure}

It is clear that the Mesopotamian textual record portrays infant loss as lamentable. This is, however, not the full picture. Although there is no convincing evidence of infanticide in ancient Mesopotamia, the practice of infant exposure is amply attested. ${ }^{151}$ Exposure entails the abandonment of a newborn infant by its begetters and caregivers, who deposit it at a certain location and leave it to an uncertain fate that can include death. Infant exposure has been documented in a great many times and places, and infants continue to be abandoned in modern societies in appreciable numbers. In his thorough study of infant exposure in Europe between Late Antiquity and the Renaissance, John Boswell found a variety of motivations for the practice and also concluded that most exposed infants could expect to survive:

Parents abandoned their offspring in desperation when they were unable to support them, due to poverty or disaster; in shame, when they were unwilling to keep them because of their physical condition or ancestry (e.g., illegitimate or incestuous); in self-interest or the interest of another child, when inheritance or domestic resources would be compromised by another mouth; in hope, when they believed someone of greater means or higher standing might find them and bring them up in better circumstances; in resignation, when a child was of unwelcome gender or ominous auspices; or in callousness, if they simply could not be bothered with parenthood. Most abandoned children were rescued and brought up either as adopted members of another household or as labourers of some sort. ${ }^{152}$

Infant exposure could be motivated by a variety of reasons, and exposed infants appear to have had a reasonable chance of survival. The reasons for infant exposure enumerated by Boswell are generic and are not substantively different from those that would have applied in ancient Mesopotamia. ${ }^{153}$

151 For the distinction between infant exposure and infanticide, see J. Evans Grubbs, "Infant Exposure and Infanticide." In The Oxford Handbook of Childhood and Education in the Classical World, ed. J. Evans Grubbs and T. Parkin (New York: Oxford University Press, 2013), which underscores the point that infant exposure is not usually equivalent to infanticide in the eyes of those who engage in it.

$15^{2}$ J. Boswell, The Kindness of Strangers: The Abandonment of Children in Western Europe from Late Antiquity to the Renaissance (Chicago: University of Chicago Press, 1998): 428-429.

153 As has been noted by Cornelia Wunsch in C. Wunsch, "Findelkinder und Adoption nach neubabylonischen Quellen." Archiv für Orientforschung 50 (2003/2004): 176: "Viele seiner Beobachtungen dürften mit der nötigen Vorsicht auch auf die Verhältnisse in Mesoptamien übertragbar sein." 
Evidence for infant exposure in ancient Mesopotamia has been catalogued in a general sense by Meir Malul and with particular attention to the NeoBabylonian period by Cornelia Wunsch. ${ }^{154}$ The easiest way to identify exposed infants in the Mesopotamian textual record is by reference to their name or to expressions used to qualify their identity. As Malul documents, phrases like "he who does not know his father or mother" ( ̌́a abašu ummašu lā $\bar{\imath} d \hat{u})$, "he was found in a well" (in būrti atûšu), "brought in from the street" (ina sūqi šürubu), "he was seized from the mouth of a dog" (ina pî kalbi ekimšu), and "rescued from the raven's mouth" (ina pî aribi ušaddi), along with names like

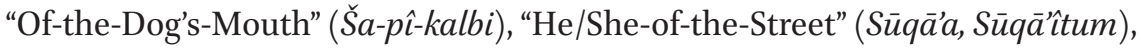
and "Spared-from-the-Dog's-Mouth" (Ina-pi-kalbi-irihh), all suggest individuals who have been abandoned by their birth parents, even if this need not be true in each and every instance. ${ }^{155}$ These names should not be taken too literally; the name $\breve{S} a-p \bar{\imath}-k a l b i$ and its derivations do not, for example, imply that an infant was ever actually in a dog's mouth, but refer instead to the legal relinquishing of parental rights over an infant - which is reflected in the liminal character of dogs. ${ }^{156}$ In one Neo-Babylonian legal text, a woman symbolically abandons her son to 'the dog's mouth' - thereby relinquishing her parental rights - whence another individual 'picks it up', thereby acquiring parental rights. ${ }^{157}$ A comparable legal formula involving the picking up of an infant while still wet with amniotic fluid — ina mêšu — also points to parental relinquishing of rights over an infant immediately following birth. ${ }^{158}$

The very fact that surviving foundlings can be identified in the Mesopotamian textual record indicates that their exposure was not always and perhaps not generally tantamount to death ${ }^{159}$ _ and that infants did have some value, as

154 M. Malul, "Adoption of Foundlings in the Bible and Mesopotamian Documents: A Study of Some Legal Metaphors in Ezekiel 16:1-7." Journal for the Study of the Old Testament 46 (1990), and Wunsch, "Findelkinder und Adoption".

155 Ibid.: 105 .

156 Wunsch, "Findelkinder und Adoption": 182-183, and Malul, "Adoption of Foundlings": 104-106. Wunsch cautions that we should not assume that an individual was actually exposed whenever names or phrases suggestive of infant exposure are used; on the name Ša-pi-kalbi, note Wunsch p. 175: "Daß dies als terminus technicus für die Aufnahme eines Findelkindes verwendet wird, ist seit langem bekannt."

157 The text is re-edited as no. 4 in Wunsch, "Findelkinder und Adoption": 219-221; see further pp. 178-182. The text is also commented upon by Meir Malul in Malul, "Adoption of Foundlings": 104.

158 Ibid.: 106, and Garroway, Children in the Ancient Near Eastern Household: 100-101.

159 Pace M. Malul, "Some Measures of Population Control in the Ancient Near East." In Michael: Historical, Epigraphical and Biblical Studies in Honor of Prof. Michael Heltzer, 
otherwise there would be no reason at all for adopting them. Indeed, cultural expectations appear to have favoured the rescue of exposed infants, for which a legal infrastructure developed that facilitated the acquisition of rights over foundlings by those who would take care of them. A colourful depiction of infant exposure comes from the Book of Ezekiel, which-while not Mesopotamian - certainlyhasa greatdeal of directMesopotamianinfluence. ${ }^{160}$ In the relevant passage, Israel is cast in the role of the foundling whom YHWH picks up from the ground:

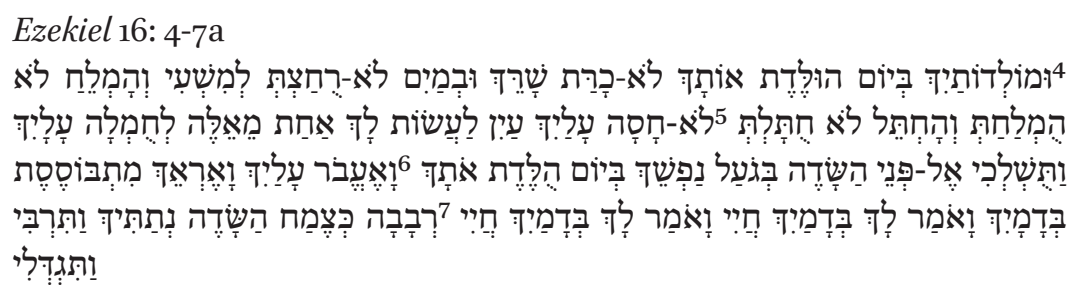

As to your birth, on the day you were born your umbilical cord was not cut, you were not washed clean with water, you were not rubbed with salt, you were not swaddled in cloth. No eye took pity on you to do any of these things for you as a mercy for you, but you were cast out to the field in your uncleanness on the day you were born. I passed by and saw you flailing about in your blood, and I said to you, "By your blood, live!" I said to you, "By your blood, live!" I made you flourish like a plant of the field and you grew and you matured.

Never mind that Israel subsequently grows up to be a harlot upon whom YHWH feels compelled to visit especially horrible punishments; the important point here is the fact that infant exposure was common enough to be depicted in the Book of Ezekiel without need for further explanation. The scene was recognizable to its audience, as was the notion that a foundling would be picked up and cared for by a third party.

Adopting foundlings is also idealized more directly in the Mesopotamian textual record. In the Sargon Birth Legend, the future king Sargon is born to an

ed. Y. Avishur and R. Deutsch (Tel Aviv: Archaeological Center Publications, 1999): 230: "Exposure was practically tantamount to the death of the infant."

16o For Mesopotamian influence in Ezekiel, see most recently A. Winitzer, "Assyriology and Jewish Studies in Tel Aviv: Ezekiel among the Babylonian Literati." In Encounters by the Rivers of Babylon: Scholarly Conversations between Jews, Iranians, and Babylonians in Antiquity, ed. U. Gabbay and S. Secunda (Tübingen: Mohr Siebeck, 2014). 
$\bar{e} n$-priestess and an unknown father with connections to the highlands. Being the product of an illicit union, Sargon is exposed by his mother, who is not in a position to care for him due to the circumstances of his conception and birth:

Sargon Birth Legend 5-11

5. İranni ummī ènetum ina puzri

ülidanni

6. iškunanni ina quppi ša šurri ina iț̣̂ bābìa iphi

\section{7. iddanni ana nāri ša lā elêa}

8. iššanni nāru ana muhhhi Aqqi dāl̂̀ übilanni

9. Aqqi dālû ina țīb dālǐšu tū ušelanni

10. Aqqi dālû ana mārūtišsu lū urabbannima

11. Aqqi dālû ana nukaribbūtǐš lū iškunanni
My mother the èn-priestess conceived me, in secret she gave birth to me.

She placed me in a reed basket, with bitumen she caulked its ${ }^{161}$ opening.

She set me in the river, from which I could not escape. The river bore me; to Aqqi the water-drawer it carried me. When lowering his bucket, Aqqi the water-drawer did lift me up. Aqqi the water-drawer raised me as his adopted son.

Aqqi the water-drawer installed me as his orchard-cultivator. ${ }^{162}$

Subsequently, the goddess Ištar favours Sargon, enabling him to rise to kingship. As in the example from the Book of Ezekiel, a pattern of exposure followed by rescue is apparent in the Sargon Birth Legend, though the outcome for Sargon is much more positive here than it is for Israel in Ezekiel. The most famous example of infant exposure in the ancient Near East and an analogue to the Sargon story is that of Moses, who is exposed in a basket that is placed in a reed-bed along the waters of the Nile before being picked up by the Pharaoh's daughter, who raises him as her own. ${ }^{163}$ Like Israel and Sargon,

161 Literally "my", but the first person suffix here refers to both Sargon and the basket, who are now one unit; what is being caulked, however, is certainly the opening of the basket and not Sargon himself.

162 Sargon Birth Legend 5-11 in B. Lewis, The Sargon Legend: A Study of the Akkadian Text and the Tale of the Hero who was Exposed at Birth (Cambridge: American Schools of Oriental Research, 1980): 24-25, and J.G. Westenholz, Legends of the Kings of Akkade: The Texts (Winona Lake: Eisenbrauns, 1997): 40-41.

163 Exodus 2: 1-10. Moses' abandonment is not, however, total: his sister watches from a distance to see what will become of the exposed baby Moses. 
Moses is exposed and rescued; like Sargon, divine favour results in Moses' elevation to leadership. Infant abandonment and rescue is thus attested in both literary and legal texts, and infant exposure and adoption were likely familiar phenomena in ancient Mesopotamia.

Although it is certain that many exposed infants were rescued by third parties, it is also undoubtedly the case that others died. There is no way to measure rates of infant exposure in ancient Mesopotamia or the statistical likelihood that exposed infants would die, but there is no reason to assume that under normal conditions exposure was practiced for anything other than a small minority of infants. Further, the practice of infant exposure does not reflect negative social attitudes to infants in general. As Cynthia Patterson argues on the basis of evidence from ancient Greece, "within discernible patterns, exposure remains an individual act carried out by individual families in individual circumstances." 164 The individual contexts of exposure are not generalizable expressions of cultural norms regarding the treatment of infants. On the contrary, there is a mythical expectation that exposed infants are to be picked up and cared for, like Sargon, Ezekiel's Israel, and Moses. This expectation is reflected prosaically in the presence of numerous foundlings in the Mesopotamian textual record. Infants continue to be abandoned today by caregivers who do not want them or who see no way to provide for them adequately, but these instances represent neither the norm nor broader socio-cultural aspirations. This also appears to have been the case in ancient Mesopotamia.

\section{Conclusion}

Infant loss in ancient Mesopotamia was in general a painful experience, though there will have been differences in how particular ancient Mesopotamian social groups responded to infant loss, how they conditioned their emotions, and how they processed the phenomenon; there will also have been those individuals who did not mourn, who did not want children, and, indeed, who abused and murdered them. To the extent that such people existed, however, their views appear not to be represented in the Mesopotamian textual record, which is remarkably uniform in its attitude to infant loss.

The 'parental indifference' approach to infant loss in pre-modern societies, whether modified or in its original formulation, sits uncomfortably with

164 C. Patterson, "'Not Worth the Rearing': The Causes of Infant Exposure in Ancient Greece." Transactions of the American Philological Association 115 (1985): 123. 
the available evidence. Further, a survey of ethnographic and anthropological research on the place of the infant in traditional societies demonstrates that caregivers in ancient Mesopotamia were likely to have been attached to their infants regardless of high levels of infant mortality. Analogues from recent research on animal grief reinforce the notion that there is a common biological underpinning informing the ways human beings of all cultures experience infants and infant loss.

Building on these conclusions, it becomes possible to approach the archaeological evidence concerning infant loss in ancient Mesopotamia with greater interpretative sensitivity. The archaeological record brings to light a great deal of data, but it is patchy and prone to multiple explanations. Nevertheless, differential infant burial practices like intramural burial and jar burial demonstrate considerable care in the manner of infant inhumation. Dead infants are not, to our knowledge, cast out like waste, but are interred respectfully in burials that not infrequently attest to considerable personalization and investment. When compared to the anthropological and ethnographic data, these burial practices-whatever their idiosyncratic cultural significance might have been in any given context - indicate that ancient Mesopotamians grieved over the passing of their infants and related to their lost little ones with some tenderness.

This impression is confirmed by the Mesopotamian textual record, which preserves a great many references to infant loss. Aetiologies exist that account for the related phenomena of infant death and the birth of severely disabled infants; the notion of the renegade infant slaughtering goddess-demon Lamaštu serves to absolve the gods of some of their culpability for infant mortality while simultaneously personifying the cruelty, malice, and viciousness that ancient Mesopotamians associated with infant loss. Overwhelmingly negative attitudes to the passing of infants along with strong expressions of mourning are apparent in many texts, from the Lamaštu literature to the Epic of Erra and Išum and correspondence from Mari. There is also copious evidence that ancient Mesopotamians struggled continuously against infant loss, using the various medical and magical means at their disposal to mount an ongoing rearguard action against the forces seeking to deprive them of their infant offspring. For those infants that did die, texts like Gilgameš, Enkidu, and the Netherworld imply that conceptualizations of the infant's place in the netherworld worked to console bereaved caregivers with the belief that the infants they had lost were not suffering, and were even enjoying themselves immensely. Practices like infant exposure do not challenge the notion that infant loss was regarded as a great evil, but illustrate instead the many 
instances when individual life stories strayed from cultural ideals. It is also clear that systems were in place to find foster homes for significant numbers of foundlings and that such fostering was considered respectable.

In his study of attitudes to child mortality in the classical world, Mark Golden argues that "we should assume that the ancients cared when their children died unless there is some compelling reason to doubt it."165 In the case of ancient Mesopotamia there is no reason at all to doubt Golden's assumption and there are a great many compelling reasons to accept it. Infant loss is regarded as an unambiguous evil, is anxiously resisted, and elicits profound and readily observable grief. The available evidence points to ancient Mesopotamia as a society that valued its infants, was invested in them, was emotionally attached to them, sought actively to protect them from harm, and mourned deeply when they died, even if they did die all too often. Golden asks whether the ancients cared when their children died. To answer his question from an ancient Mesopotamian perspective and with a focus on infants: absolutely and unequivocally, yes, the ancients did care when their children died.

\section{Bibliography}

Ainsworth, Mary D. Salter. 1977. Infant Development and Mother-Infant Interaction among Ganda and American Families. In Culture and Infancy: Variations in the Human Experience, ed. P.H. Leiderman, S.R. Tulkin, and A. Rosenfeld. New York: Academic Press: 119-149.

Albenda, Pauline. 1987. Woman, Child, and Family: Their Imagery in Assyrian Art. In La Femme dans le Proche-Orient antique, ed. J.-M. Durand. Paris: Editions Recherche sur les Civilisations: 17-21.

Alster, Bendt. 2005. Wisdom of Ancient Sumer. Bethesda: CD L Press.

Annus, Amar, and Alan Lenzi. 2010. Ludlul bèlnēmeqi: The Standard Babylonian Poem of the Righteous Sufferer. SAACT Vir. Helsinki: The Neo-Assyrian Text Corpus Project.

Archer, John. 1999. The Nature of Grief: The Evolution and Psychology of Reactions to Loss. London: Routledge.

Ariès, Philippe. 1973. Centuries of Childhood. London: Penguin.

Artin, Gassia. 2008. The Jar Burials of the Chalcolithic "Necropolis" at Byblos. In Babies Reborn: Infant/Child Burials in Pre- and Protohistory, ed. K. Bacvarov. Oxford: Archaeopress: $79-85$.

165 Golden, "Did the Ancients Care": 16o. 
Bacvarov, Krum. 2008. A Long Way to the West: Earliest Jar Burials in Southeast Europe and the Near East. In Babies Reborn: Infant/Child Burials in Pre-and Protohistory, ed. K. Bacvarov. Oxford: Archaeopress: 61-70.

Bahrani, Zainab. 2001. Women of Babylon: Gender and Representation in Mesopotamia. New York: Routledge.

Baker, Heather. 1995. Neo-Babylonian Burials Revisited. In The Archaeology of Death in the Ancient Near East, ed. S. Campbell and A. Green. Oxbow: Oxford: 209-220.

Balikci, Asen. 1967. Female Infanticide on the Arctic Coast. Man 2/4: 615-625.

Battini-Villard, Laura. 1999. L'espace domestique en Mésopotamie de la IIIe dynastie d'Ur à l'époque paléo-babylonienne. Archaeopress: Oxford.

Birney, Kathleen, and Brian R. Doak. 2011. Funerary Iconography on an Infant Burial Jar from Ashkelon. Israel Exploration Journal 61: 32-53.

Birot, Maurice. 1980. "Fragment de rituel de Mari relatif au kispum." In Death in Mesopotamia: Papers Read at the XXV ${ }^{\mathrm{e}}$ Rencontre assyriologique internationale, ed. B Alster. Copenhagen: Akademisk Forlag: 139-150.

Böck, Barbara. 2014. The Healing Goddess Gula: Toward an Understanding of Ancient Babylonian Medicine. Leiden: Brill.

Boswell, John. 1998. The Kindness of Strangers: The Abandonment of Children in Western Europe from Late Antiquity to the Renaissance. Chicago: University of Chicago Press.

Bottéro, Jean, and Samuel Noah Kramer. 1989. Lorsque les dieux faisaient l'homme. Mythologie mésopotamienne. Paris: Gallimard.

Boz, Başak, and Lori D. Hager. 2013. Living Above the Dead: Intramural Burial Practices at Çatalhöyük. In Humans and Landscapes of Çatalhöyük: Reports from the 2000-2008 Seasons, ed. I. Hodder. Los Angeles: Cotsen Institute of Archaeology Press: 413-440.

Brereton, Gareth. 2013. Cultures of Infancy and Capital Accumulation in Pre-Urban Mesopotamia. World Archaeology 45/2: 232-251.

Broad, K.D., J.P. Curley, and E.B. Keverne. 2006. Mother-Infant Bonding and the Evolution of Mammalian Social Relationships. Philosophical Transactions: Biological Sciences 361 (1476): 2199-2214.

Budin, Stephanie Lynn. 2011. Images of Woman and Child from the Bronze Age: Reconsidering Fertility, Maternity, and Gender in the Ancient World. New York: Cambridge University Press.

Cagni, Luigi. 1969. L'Epopea di Erra. Napoli: Istituto di Studi del Vicino Oriente.

Campbell, J.K. 1967. Honour, Family and Patronage: A Study of Institutions and Moral Values in a Greek Mountain Community. Oxford: Clarendon Press.

Carroll, Maureen. 2012. "No Part in Earthly Things". The Death, Burial and Commemoration of Newborn Children and Infants in Roman Italy. In Families in the Roman and Late Antique World, ed. M. Harlow and L. Larsson Lovén. London: Continuum: 41-63. 
Cooper, Jerrold S. 2009. Wind and Smoke: Giving up the Ghost of Enkidu, Comprehending Enkidu's Ghosts. In Rethinking Ghosts in World Religions, ed. Mu-chou Poo. Leiden: Brill: $23-32$.

Crawford, Sally. 2009. The Archaeology of Play Things: Theorising a Toy Stage in the 'Biography' of Objects. Childhood in the Past 2: 55-70.

Danti, Michael D. 2013. Hasanlu V: The Late Bronze and Iron I Periods. Philadelphia: University of Pennsylvania Press.

Draffkorn Kilmer, Anne. 1976. Speculations on Umul, the First Baby. In Kramer Anniversary Volume: Sumerological Studies in Honour of Samuel Noah Kramer, ed. B.L. Eichler. Kevelaer: Butzon \& Bercker: 266-270.

Draffkorn Kilmer, Anne. 1993. Games and Toys in Ancient Mesopotamia. In Actes du XII ${ }^{e}$ Congrès International des Sciences Préhistoriques et Protohistoriques, Bratislava, 1.7 Septembre 1991, ed. J. Pavúk. Bratislava: Institut Archeologique de l'Academie Slovaque des Sciences: 359-364.

Dunham, Sally. 1993. Beads for Babies. Zeitschrift für Assyriologie und Vorderasiatische Archäologie 83: 237-257.

Durand, Jean-Marie. 1988. Archives épistolaires de Mari. Archives Royales de Mari XXVI. Paris: Recherches sur les Civilisations.

Evans Grubbs, Judith. 2013. Infant Exposure and Infanticide. In The Oxford Handbook of Childhood and Education in the Classical World, ed. J. Evans Grubbs and T. Parkin. New York: Oxford University Press: 83-107.

Farber, Walter. 1989. Schlaf, Kindchen, Schlaf! Mesopotamische Baby-Beschwörungen und-Rituale. Winona Lake: Eisenbrauns.

Farber, Walter. 2014. Lamaštu: An Edition of the Canonical Series of Lamaštu Incantations and Rituals and Related Texts from the Second and First Millennia B.C. Winona Lake: Eisenbrauns.

Finley, M.I. 1981. The Elderly in Classical Antiquity. Greece \& Rome 28/2: 156-171.

Freed, Ruth S., and Stanley A. Freed. 1989. Beliefs and Practices Resulting in Female Deaths and Fewer Females than Males in India. Population and Environment 10/3: 144-161.

Gadotti, Alhena. 2014. Gilgamesh, Enkidu, and the Netherworld, and the Sumerian Gilgamesh Cycle. Berlin: De Gruyter.

Galbally, Megan, Andrew James Lewis, Marinus van Ijzendoorn, and Michael Permezel. 2011. The Role of Oxytocin in Mother-Infant Relations: A Systematic Review of Human Studies. Harvard Review of Psychiatry 19/1: 1-14.

Gardeła, Leszek, and Paweł Duma. 2013. Untimely Death: Atypical Burials of Children in Early and Late Medieval Poland. World Archaeology 45/2: 314-332.

Garroway, Kristine Henriksen. 2014. Children in the Ancient Near Eastern Household. Winona Lake: Eisenbrauns. 
Geller, Markham J. 1997. Freud, Magic and Mesopotamia: How the Magic Works. Folklore 108: 1-7.

George, Andrew R. 2003. The Babylonian Gilgamesh Epic: Introduction, Critical edition and Cuneiform Texts, Volume I. New York: Oxford University Press.

Georgiadis, Mercourios. 2011. Child Burials in Mesolithic and Neolithic Southern Greece: A Synthesis. Childhood in the Past 4: 31-45.

Golden, Mark. 1988. Did the Ancients Care when their Children Died? Greece \& Rome 35/2: 152-163.

Golden, Mark. 2004. Mortality, Mourning and Mothers. In Naissance et petite enfance dans l'Antiquité: Actes du colloque de Fribourg, 28 novembre - ier décembre 2001, ed. V. Dasen. Fribourg: Academic Press Fribourg: 145-157.

Gordon, Ilanit, Orna Zagoory-Sharon, James F. Leckman, and Ruth Feldman. 2010. Oxytocin and the Development of Parenting in Humans. Biological Psychiatry 68/4: 377-382.

Götting, Eva. 2011. Exportschlager Dämon? Zur Verbreitung Altorientalischer LamaštuAmulette. In Exportschlager: Kultureller Austausch, wirtschaftliche Beziehungen und transnationale Entwicklungen in der antiken Welt, ed. J. Göbel and T. Zech. Berlin: Herbert Utz: 437-456.

Graff, Sarah B. 2014. Sexuality, Reproduction and Gender in Terracotta Plaques from the Late Third-Early Second Millennia BCE. In Critical Approaches to Ancient Near Eastern Art, ed. B.A. Brown and M.H. Feldman. Berlin: De Gruyter: 371-39o.

Guy, Hervé, Claude Masset, and Charles-Albert Baud. 1997. Infant Taphonomy. International Journal of Osteoarchaeology 7: 221-229.

Hafford, Brad. Ur Digitization Project: June 2014. Published June 23, 2014, at http:// www.penn.museum/blog/museum/ur-digitization-project-june-2014/, accessed on April 6, 2015.

Haller, Arndt. 1954. Die Gräber und Grüfte von Assur. Wissenschaftliche Veröffentlichungen der Deutschen Orient-Gesellschaft 65. Berlin: Verlag Gebr. Mann.

Harris, Rivkah. 2000. Gender and Aging in Mesopotamia: The Gilgamesh Epic and other Ancient Literature. Norman: The University of Oklahoma Press.

Hawkes, Kristen. 1981. A Third Explanation for Female Infanticide. Human Ecology 9/1: 79-96.

Heeßel, Nils P. 200o. Babylonisch-assyrische Diagnostik. Münster: Ugarit-Verlag.

Heffron, Yağmur. 2014. Revisiting 'Noise' (rigmu) in Atra-hasīs in Light of Baby Incantations. JNES 73.1: 83-93.

Hillson, Simon. 2009. The World's Largest Infant Cemetery and Its Potential for Studying Growth and Development. Hesperia Supplements 43: 137-154.

Hirasawa, Ayako. 2005. "Infant Care among the Sedentarized Baka Hunter-Gatherers in Southeastern Cameroon." In Hunter-Gatherer Childhoods: Evolutionary, 
Developmental and Cultural Perspectives, ed. B.S. Hewlett and M.E. Lamb. New Brunswick: Transaction Publishers: 365-384.

Ilan, David. 1995. Mortuary Practices at Tel Dan in the Middle Bronze Age: A Reflection of Canaanite Society and Ideology. In The Archaeology of Death in the Ancient Near East, ed. S. Campbell and A. Green. Oxford: Oxbow: 117-139.

Jacobsen, Thorkild, et al. 1949. Before Philosophy: The Intellectual Adventure of Ancient Man. Baltimore: Penguin.

Jacobsen, Thorkild. 1987. The Harps that Once ... Sumerian Poetry in Translation. New Haven: Yale University Press.

Johnston, Sarah Iles. 1995. Defining the Dreadful: Remarks on the Greek Child-Killing Demon. In Ancient Magic and Ritual Power, ed. M. Meyer and P. Mirecki. Leiden: Brill: $361-387$.

King, Barbara J. 2013a. How Animals Grieve. Chicago: University of Chicago Press. King, Barbara J. 2013b. When Animals Mourn. Scientific American 309: 62-67.

Köcher, Franz. 1963. Die babylonisch-assyrische Medizin in Texten und Untersuchungen. Berlin: De Gruyter.

Koepf-Taylor, Laurel W. 2013. Give Me Children or I shall Die: Children and Communal Survival in Biblical Literature. Minneapolis: Fortress Press.

Konner, Melvin. 2005. Hunter-Gatherer Infancy and Childhood: The !Kung and Others. In Hunter-Gatherer Childhoods: Evolutionary, Developmental and Cultural Perspectives, ed. B.S. Hewlett and M.E. Lamb. New Brunswick: Transaction Publishers: 19-64. Kramer, Samuel Noah, and John Maier. 1989. Myths of Enki, the Crafty God. New York: Oxford University Press.

Kulemann-Ossen, Sabina, and Mirko Novák. 2000. 'Kūbu und das "Kind im Topf." Altorientalische Forschungen 27: 121-131.

Labat, René. 1951. Traité akkadien de diagnostics et pronostics médicaux. Leiden: Brill. Lambert, W.G. 1969. A Middle Assyrian Medical Text. Iraq 31: 28-39.

Lambert, W.G. 1980-1983. Kūbu. In Reallexikon der Assyriologie und vorderasiatische Archäologie, Band VI: Klagesang - Libanon, ed. E. Ebeling et al. Berlin: De Gruyter: 265 .

Lambert, W.G. 2013. Babylonian Creation Myths. Winona Lake: Eisenbrauns.

Lambert, W.G., and A.R. Millard. 1999. Atra-hasiss: The Babylonian Story of the Flood. Winona Lake: Eisenbrauns.

Lancy, David F. 2014. “Babies Aren't Persons”: A Survey of Delayed Personhood. In Different Faces of Attachment: Cultural Variations of a Universal Human Need, ed. H. Otto and H. Keller. Cambridge: Cambridge University Press: 66-109.

Lapinkivi, Pirjo. 2010. The Neo-Assyrian Myth of Ištar's Descent and Resurrection. SAACT VI. Helsinki: The Neo-Assyrian Text Corpus Project.

Leichty, Erle. 1970. The Omen Series Šumma Izbu. Locust Valley: J.J. Augustin. 
LeVine, Robert A. 1977. Child Rearing as Cultural Adaptation. In Culture and Infancy: Variations in the Human Experience, ed. P.H. Leiderman, S.R. Tulkin, and A. Rosenfeld. New York: Academic Press: 15-27.

Lewis, Brian. 1980. The Sargon Legend: A Study of the Akkadian Text and the Tale of the Hero who was Exposed at Birth. Cambridge: American Schools of Oriental Research.

Lewis, Michael, and Peggy Ban. 1977. Variance and Invariance in the Mother-Infant Interaction: A Cross-Cultural Study. In Culture and Infancy: Variations in the Human Experience, ed. P.H. Leiderman, S.R. Tulkin, and A. Rosenfeld. New York: Academic Press: 329-355.

Lindenlauf, Astrid. 2001. Thrown Away Like Rubbish—Disposal of the Dead in Ancient Greece. Papers from the Institute of Archaeology 12: 86-99.

Liston, Maria A., and Susan I. Rotroff. 2013. Babies in the Well: Archeological Evidence for Newborn Disposal in Hellenistic Greece. In The Oxford Handbook of Childhood and Education in the Classical World, ed. J. Evans Grubbs and T. Parkin. New York: Oxford University Press: 62-82.

Malul, Meir. 1990. Adoption of Foundlings in the Bible and Mesopotamian Documents: A Study of Some Legal Metaphors in Ezekiel 16:1-7. Journal for the Study of the Old Testament 46: 97-126.

Malul, Meir. 1999. Some Measures of Population Control in the Ancient Near East. In Michael: Historical, Epigraphical and Biblical Studies in Honor of Prof. Michael Heltzer, ed. Y. Avishur and R. Deutsch. Tel Aviv: Archaeological Center Publications: 221-236.

McGeorge, P.J.P. 2011. Intramural Infant Burials in the Aegean Bronze Age. In 2èmes Rencontres d'archéologie de l'IFEA: Le Mort dans la ville Pratiques, contextes et impacts des inhumations intra-muros en Anatolie, du début de l'Age du Bronze à l'époque romaine, Nov 2011, Istanbul, Turkey, ed. O. Henry. Istanbul: IFEA-Ege yayınları: 1-20.

McMahon, Augusta. 2006. Nippur V: The Early Dynastic to Akkadian Transition: The Area WF Sounding at Nippur. Chicago: The Oriental Institute.

Meyers, Carol. 2013. Rediscovering Eve: Ancient Israelite Women in Context. New York: Oxford University Press.

Moore, Alison. 2009. Hearth and Home: The Burial of Infants within Romano-British Domestic Contexts. Childhood in the Past 2: 33-54.

Moss, Howard A., and Sandra J. Jones. 1977. Relations Between Maternal Attitudes and Maternal Behavior As a Function of Social Class. In Culture and Infancy: Variations in the Human Experience, ed. P.H. Leiderman, S.R. Tulkin, and A. Rosenfeld. New York: Academic Press: 439-467.

Nagasawa, Miho, Shota Okabe, Kazutaka Mogi, and Takefumi Kikusui. 2012. Oxytocin and Mutual Communication in Mother-Infant Bonding. Frontiers in Human Neuroscience 6: 31 . 
Orrelle, Estelle. 2008. Infant Jar Burials - A Ritual Associated with Early Agriculture? In Babies Reborn: Infant/Child Burials in Pre- and Protohistory, ed. K. Bacvarov. Oxford: Archaeopress: 71-78.

Parkin, Tim. 2013. The Demography of Infancy and Early Childhood in the Ancient World. In The Oxford Handbook of Childhood and Education in the Classical World, Ed. J. Evans Grubbs and T. Parkin. New York: Oxford University Press: 40-61.

Parpola, Simo. 1993. Letters from Assyrian and Babylonian Scholars. State Archives of Assyria, Volume x. Helsinki: Helsinki University Press.

Pasquali, Jacopo. 2013. Symbolique de mort et de renaissance dans les cultes et les rites éblaïtes: dga-na-na, les ancêtres et la royauté. Revue d'Assyriologie 107: 43-70.

Patterson, Cynthia. 1985. "Not Worth the Rearing": The Causes of Infant Exposure in Ancient Greece. Transactions of the American Philological Association 115: 103-123.

Pérez de Heredia, Eduardo, et al. 2005. Un Patrón de Entierros Infantiles en Vasijas durante la Transición del Clásico Tardío al Terminal en Chichen Itza, Yucatán. In XVIII Simposio de Investigaciones Arqueológicas en Guatemala, 2004, ed. J.P. LaPorte, B. Arroyo, and H.E. Mejía. Guatemala: Ministerio de Cultura y Deportes.

Pollock, Linda A. 1983. Forgotten Children:Parent-Child Relations from 1500 to 190o. Cambridge: Cambridge University Press.

Postgate, J. Nicholas. 1992. Early Mesopotamia: Society and Economy at the Dawn of History. New York: Routledge.

Potts, Daniel T. 1997. Mesopotamian Civilization: The Material Foundations. Ithaca: Cornell University Press.

Reuther, Oscar. 1926. Die Innenstadt von Babylon (Merkes). Wissenschaftliche Veröffentlichungen der Deutschen Orient-Gesellschaft 47. Leipzig: J.C. Hinrichs.

Römer, W.H. Ph. 1973. Einige Bemerkungen zum dämonischen Gotte ${ }^{\mathrm{d}} \mathrm{Ku} b u(\mathrm{~m})$. In Symbolae Biblicae et Mesopotamicae: Francisco Mario Theodoro de Liagre Dedicatae, ed. M.A. Beek et al. Leiden: Brill: 310-319.

Rosenwein, Barbara H. 2002. Worrying about Emotions in History. The American Historical Review 107/3: 821-845.

Safina, Carl. 2015. Beyond Words: What Animals Think and Feel. New York: Henry Holt.

Scott, Eleanor. 1999. The Archaeology of Infancy and Infant Death. Oxford: Archaeopress.

Scurlock, JoAnn, and Burton R. Andersen. 2005. Diagnoses in Assyrian and Babylonian Medicine: Ancient Sources, Translations, and Modern Medical Analyses. Urbana: University of Illinois Press.

Sharot, Tali. 2011. The Optimism Bias. Current Biology 21/23: R941-R945.

Shorter, Edward. 1975. The Making of the Modern Family. New York: Basic Books.

Skaist, Aaron. 1980. The Ancestor Cult and Succession in Mesopotamia. In Death in Mesopotamia: Papers Read at the XXVI Rencontre assyriologique internationale, ed. B Alster. Copenhagen: Akademisk Forlag: 123-128. 
Starr, Richard F.S. 1939. Nuzi: Report on the Excavations at Yorgan Tepa near Kirkuk, Iraq, Conducted by Harvard University in Conjunction with the American Schools of Oriental Research and the University Museum of Philadelphia, 1927-1931: Volume I, Text. Cambridge: Harvard University Press.

Stearns, Peter N., and Carol Z. Stearns. 1985. Emotionology: Clarifying the History of Emotions and Emotional Standards. The American Historical Review 9o/4: 813-836.

Stein, Gil J. 2011. Tell Zeidan. In Oriental Institute Annual Report 2010-2011, ed. G.J. Stein. Chicago: The Oriental Institute: 122-139.

Stol, M. 2000. Birth in Babylonia and the Bible: Its Mediterranean Setting. Groningen: Styx.

Stone, Lawrence. 1977. The Family, Sex and Marriage in England 1500-1800. New York: Harper \& Row.

Stortz, Mary Ellen. 2001. "Where or When Was Your Servant Innocent?" Augustine on Childhood. In The Child in Christian Thought, ed. M.J. Bunge. Grand Rapids: Eerdmans: 78-102.

Suter, Claudia E. 2008. Who are the Women in Mesopotamian Art from ca. 2334-1763 BCE? Kaskal 5: 1-55.

Toorn, Karel van der. 1999. Magic at the Cradle: A Reassessment. In Mesopotamian Magic: Textual, Historical, and Interpretative Perspectives, ed. T. Abusch and K. van der Toorn. Groningen: Styx: 139-147.

Tsukimoto, Akio. 1980. Aspekte von kispu $(m)$ als “Totenbeigabe." In Death in Mesopotamia: Papers Read at the XXVI Rencontre assyriologique internationale, ed. B Alster. Copenhagen: Akademisk Forlag: 129-138.

Volk, Konrad. 1999. Kinderkrankheiten nach der Darstellung babylonisch-assyrischer Keilschrifttexte. Orientalia Nova Series 68/1: 1-30.

Westenholz, Aage. 2010. Enki and Ninmah: An Interpretation. In A Woman of Valor: Jerusalem Ancient Near Eastern Studies in Honor of Joan Goodnick Westenholz, ed. W. Horowitz, U. Gabbay, and F. Vukosavović. Madrid: Consejo Superior de Investigaciones Científicas: 201-204.

Westenholz, Joan Goodnick. 1997. Legends of the Kings of Akkade: The Texts. Winona Lake: Eisenbrauns.

Wiggermann, F.A.M. 2000. Lamaštu, Daughter of Anu: A Profile. In Birth in Babylonia and the Bible: Its Mediterranean Setting, by M. Stol. Groningen: Styx: 217-249.

Wiggermann, F.A.M. 2003-2005. Pāšittu. In Reallexikon der Assyriologie und Vorderasiatische Archäologie, 10. Band. Berlin: De Gruyter: 363-364.

Wilhelm, Klaus. 2006. Do Animals Have Feelings? Scientific American Mind 17: 25-29.

Winitzer, Abraham. 2014. Assyriology and Jewish Studies in Tel Aviv: Ezekiel among the Babylonian Literati. In Encounters by the Rivers of Babylon: Scholarly Conversations between Jews, Iranians, and Babylonians in Antiquity, ed. U. Gabbay and S. Secunda. Tübingen: Mohr Siebeck: 163-216. 
Woods, Robert. 2006. Children Remembered: Responses to Untimely Death in the Past. Liverpool: Liverpool University Press.

Woods, Robert. 2007. Ancient and Early Modern Mortality: Experience and Understanding. The Economic History Review 6o/2: 373-399.

Woods, Robert. 2009. Death before Birth: Fetal Health and Mortality in Historical Perspective. New York: Oxford University Press.

Woolley, Leonard, and Mallowan, Max. 1976. Ur Excavations, Volume VII: The Old Babylonian Period. London: The Trustees of the British Museum and the University Museum, Philadelphia.

Wunsch, Cornelia. 2003/2004. Findelkinder und Adoption nach neubabylonischen Quellen. Archiv für Orientforschung 50: 174-244.

Zettler, Richard L. 1993. Nippur III: Kassite Buildings in Area WC-ı. Chicago: Oriental Institute. 